\title{
Post-COVID Syndrome. A Case Series and Comprehensive Review
}

\author{
Juan-Manuel Anaya ${ }^{1,2 *}$, Manuel Rojas ${ }^{1}$, Martha L. Salinas ${ }^{2}$, Yhojan Rodríguez ${ }^{1,2}$, \\ Geraldine Roa ${ }^{1}$, Marcela Lozano ${ }^{1}$, Mónica Rodríguez-Jiménez ${ }^{1}$, Norma Montoya ${ }^{2}$, \\ Elizabeth Zapata ${ }^{1}$, Post-COVID study group ${ }^{3}$, Diana M Monsalve ${ }^{1}$, \\ Yeny Acosta-Ampudia ${ }^{1}$, Carolina Ramírez-Santana ${ }^{1}$
}

${ }^{1}$ Center for Autoimmune Diseases Research (CREA), School of Medicine and Health Sciences, Universidad del Rosario, Bogotá, Colombia

${ }^{2}$ Clínica del Occidente, Bogotá, Colombia

${ }^{3}$ School of Medicine and Health Sciences, Universidad del Rosario, Bogotá, Colombia

\section{Corresponding author}

Juan-Manuel Anaya, MD, PhD.

Center for Autoimmune Diseases Research (CREA), School of Medicine and

Health Sciences, Universidad Del Rosario,

Carrera 24 \# 63c 69, 110010 Bogotá, Colombia.

E-mail address: juan.anaya@urosario.edu.co 


\section{Highlights}

- PCS is mainly characterized by musculoskeletal, pulmonary, digestive and neurological involvement including depression.

- PCS is independent of severity of acute illness and humoral immune response.

- Autonomic symptoms may help to classify patients with PCS.

- Long-term antibody responses to SARS-CoV-2 infection and a high interindividual variability were confirmed. 


\section{Abbreviations}

Cl: Confidence interval.

COMPASS 31: Composite autonomic symptom score 31.

COVID-19: Coronavirus disease 2019.

$D_{\text {Lco: }}$ Diffusing capacity for carbon monoxide.

ECLIA: Electrochemiluminescence immunoassay.

ELISA: Enzyme-linked immunosorbent assay.

ICU: Intensive care unit.

IQR: Interquartile range.

NA: Not applicable/available.

PCS: Post-COVID syndrome.

POTS: Postural orthostatic tachycardia syndrome.

PRISMA: Preferred Reporting Items for Systematic Reviews and Meta-analyses.

RBD: Receptor binding domain.

S/Co: Signal-to-cut-off.

SARS-CoV-2: Severe acute respiratory syndrome coronavirus 2.

TNF: Tumor necrosis factor. 
medRxiv preprint doi: https://doi.org/10.1101/2021.07.17.21260655; this version posted July 20, 2021. The copyright holder for this preprint (which was not certified by peer review) is the author/funder, who has granted medRxiv a license to display the preprint in perpetuity.

All rights reserved. No reuse allowed without permission.

\section{Abstract}

The existence of a variety of symptoms with a duration beyond the acute phase of COVID-19, is referred to as post-COVID syndrome (PCS). We aimed to report a series of patients with PCS attending a Post-COVID Unit and offer a comprehensive review on the topic. Adult patients with previously confirmed SARS-CoV-2 infection were systematically assessed through a semi-structured and validated survey. Total IgG, IgA and IgM serum antibodies to SARS-CoV-2 were evaluated by an electrochemiluminescence immunoassay. A systematic review of the literature and meta-analysis were conducted, following PRISMA guidelines. Univariate and multivariate methods were used to analyze data. Out of a total of 100 consecutive patients, 53 were women, the median of age was 49 years (IQR: 37.8 to 55.3), the median of post-COVID time after the first symptoms was 219 days (IQR: 143 to 258), and 65 patients were hospitalized during acute COVID-19. Musculoskeletal, digestive (i.e., diarrhea) and neurological symptoms including depression (by Zung scale) were the most frequent observed in PCS patients. A previous hospitalization was not associated with PCS manifestation. Arthralgia and diarrhea persisted in more than $40 \%$ of PCS patients. The median of anti-SARS-CoV-2 antibodies was 866.2 U/mL (IQR: 238.2 to 1681). Despite this variability, 98 patients were seropositive. Based on autonomic symptoms (by COMPASS 31) two clusters were obtained with different clinical characteristics. Levels of anti-SARS-CoV-2 antibodies were not different between clusters. A total of 40 articles (11,196 patients) were included in the meta-analysis. Fatigue/muscle weakness, dyspnea, pain and discomfort, anxiety/depression and impaired 
concentration were presented in more than $20 \%$ of patients reported. In conclusion, PCS is mainly characterized by musculoskeletal, pulmonary, digestive and neurological involvement including depression. PCS is independent of severity of acute illness and humoral response. Long-term antibody responses to SARSCoV-2 infection and a high inter-individual variability were confirmed. Future studies should evaluate the mechanisms by which SARS-CoV-2 may cause PCS and the best therapeutic options.

Key words: Post-COVID syndrome, post-COVID, long COVID, prolonged COVID, post-acute COVID-19, COVID-19. 


\section{Introduction}

During acute infection of severe acute respiratory syndrome coronavirus 2 (SARSCoV-2), responsible of the coronavirus disease 2019 (COVID-19), symptoms vary from mild forms to critical and more severe cases [1-3]. Symptoms in the mildest forms include dry cough, fatigue, anosmia, and fever. On the other hand, in the most severe forms, the symptoms can progress to respiratory failure requiring invasive mechanical ventilation [2,4,5]. Although most of the COVID-19 patients recover completely, without sequelae, many patients may continue experiencing COVID-19 symptoms after recovery and others may even develop new symptoms [6]. Altogether, this clinical spectrum occurring after acute infection is called postCOVID syndrome (PCS) [7]. Some authors have defined PCS as the presence of signs and symptoms after acute COVID-19 infection for more than 12 weeks $[8,9]$.

Among the most frequently reported PCS symptoms are fatigue, headache, attention deficit, hair loss, dyspnea, myalgia, and arthralgia [10]. However, a wide variety of symptoms have been reported within the PCS involving multiple organs and systems demanding long-term follow-up [8,9], and even rehospitalization due to severity of PCS. In addition, most of these patients have comorbidities such as cardiovascular diseases, diabetes mellitus, obesity, cancer, and chronic kidney diseases $[8,9]$. Therefore, it is crucial to understand the heterogeneity of PCS. The objective of this work was to describe the clinical and serological characteristics (i.e., antibodies anti-SARS-CoV-2) of the first 100 consecutive post-COVID 
patients attending a post-COVID Unit in Bogota, Colombia. In addition, we conducted a systematic review and meta-analysis on the topic.

\section{Methods}

\subsection{Study design}

A cross-sectional study was conducted from March $18^{\text {th }}$ to May $20^{\text {th }}, 2021$, at the post-COVID Unit lead by the Center for Autoimmune Diseases Research (CREA) at the Clínica del Occidente in Bogotá, Colombia. Patients older than 18 and previously confirmed SARS-CoV-2 by PCR in swab or sputum were invited to voluntary attend the post-COVID unit. The first 116 consecutive patients attending the post-COVID unit were assessed. Then, patients with history of vaccination against SARS-CoV-2 (n: 10), autoimmune diseases prior acute COVID-19 (n: 2), and patients without confirmed COVID-19 (n: 4) were excluded. A final sample size of 100 patients was included in the analyses. Of these patients, seven were asymptomatic during acute COVID-19.

Patients were systematically evaluated for post-COVID manifestations (see below), including depression and autonomic symptoms by validated scales, as well as for clinical characteristics during the acute COVID-19. All patients were tested for total anti-SARS-CoV-2 antibodies (see below for details). This study was done in compliance with Act $008430 / 1993$ of the Ministry of Health of the Republic of Colombia, which classified it as minimal-risk research. All the patients were asked for their consent and were informed about the Colombian data protection law (1581 
of 2012). The institutional review board of the Universidad del Rosario approved the study design.

\subsection{Survey validation}

A semi-structured survey was constructed based on internationally validated questionnaires that sought information during and after COVID-19 acute infection [11-15]. It was validated by a consensus of expert physicians. Once validation and approval were obtained, a pilot test was done in a group of 30 volunteers. The pilot phase allowed to identify additional questions to assess systemic compromise, to organize queries, and adapt them to guarantee its interpretability by the respondent.

\subsection{Survey and data collection}

A total of 177 questions were included in the semi-structured survey, and distributed in the following areas: identification and consent, 6; sociodemographic and epidemiological characteristics, 12; past medical history, 15; diagnosis and clinical presentation of acute COVID-19, 29; current general state of health, 4; constitutional symptoms, 4; neuropsychological (including the composite autonomic symptom score 31 [COMPASS 31] and Zung scales), 58; sense organs, 10; cardiovascular, 6; pulmonary, 8; musculoskeletal, 11; dermatological, 4; gastrointestinal, $3 ; \quad$ and COVID-19 vaccination information, 7 (https://forms.gle/QeD96DY6NZz53hAy7). All data were collected in an electronic and secure database as described elsewhere [16]. Depression was assessed by 
the Zung scale. This feature was categorized as follows: Zung score $<40$ absence of depression, and Zung score $\geq 40$ depression [17]. Autonomic symptoms were evaluated by COMPASS $31[14,18]$.

\subsection{Antibodies anti-SARS-CoV2}

Total IgG, IgA and IgM antibodies to SARS-CoV-2 were evaluated in serum samples through the Elecsys Anti-SARS-CoV-2 electrochemiluminescence immunoassay "ECLIA" (Roche Diagnostics International AG, Rotkreuz, Switzerland). The Elecsys anti-SARS-CoV-2 $S$ assay detects antibodies to SARS-CoV-2 Receptor Binding Domain (RBD) in a double-antigen sandwich assay format. The protocol was followed according to manufacturer instructions. Positive results by the ECLIA require a signal-to-cut-off $(\mathrm{S} / \mathrm{Co})$ value of $\geq 0.80$ $\mathrm{U} / \mathrm{mL}$. Serum samples were initially analyzed directly without dilution, in case of results $>250 \mathrm{U} / \mathrm{mL}$, the serum sample was diluted 1:10, according to manufacturer's recommendations. An internal validation procedure was performed, that included samples previously tested by enzyme-linked immunosorbent assay (ELISA, Euroimmun, Luebeck, Germany), and a neutralizing antibody assay (Supplementary material 1).

\subsection{Information sources and search strategy for systematic review}

A systematic review of the literature was done following the Preferred Reporting Items for Systematic Reviews and Meta-analyses (PRISMA) guideline [19]. PubMed was systematically searched for published and unpublished studies. 
Additional manual searches of the references cited in the articles were done. The search included articles up to May $8^{\text {th }}, 2021$. No restrictions were placed on study period or sample size. Other information sources such as personal communications and author's repositories were included. Terms used for this search were: ("Post-COVID” OR "Long COVID”) AND (“COVID-19”). Articles in Spanish and English were included.

\subsection{Eligibility criteria}

Studies meeting the following criteria were included: (a) studies describing clinical manifestations after acute COVID-19, (b) studies evaluating patients in clinical settings, (c) case series, cross-sectional, case-control, cohort, or clinical trial studies were also included, (d) studies including data from national registries or unaudited databases were excluded.

\subsection{Study selection}

Study selection was done independently by three reviewers (i.e., GR, ML, JMA) who evaluated studies for eligibility in a two-step procedure. In the first phase, all identified titles and abstracts were evaluated to ensure the relationship with PCS. The potentially relevant articles were subsequently selected and evaluated again in the second phase. Here, a full-text review was done to determine whether the studies effectively reported the data about the clinical features of PCS. Retrieved articles were rejected if the eligibility criteria were not meet, and a fourth reviewer (i.e., MRJ) was consulted in cases in which the eligibility criteria were not clear. 


\subsection{Data extraction and quality assessment}

Data were extracted using a standardized form to include the following variables: author, country, region, age, gender, post-COVID time, and clinical features as specified for our clinical study. A single author (i.e., GR) extracted the information, and a second reviewer (i.e., ML) verified the extracted information. Any discrepancies or missing information were resolved by consensus.

Given the discrepancies across the studies regarding the reporting of clinical manifestations, several clinical features were gathered to improve the reliability and interpretability of meta-analysis. These clinical manifestations included: impaired concentration, cognitive impairment, asthenia, dementia, polyneuropathy, heat intolerance/flushing, dizziness, headache, dysautonomia, blurry vision, xeropthalmia/sicca symptoms, nasal congestion, sneezing/coryza, palpitations, diarrhea/vomiting, dyspepsia, fatigue, arthralgia/myalgia, dyspnea, pleuritic pain, myocarditis, anxiety/depression, burning feet pain, fever, insomnia/sleep disorders. Evaluation of quality of the eligible studies was not performed. The PRISMA flowchart for systematic reviews is presented in Figure 1.

\subsection{Statistical analysis}

Univariate descriptive statistics were performed. Categorical variables were analyzed using frequencies, and quantitative continuous variables were expressed the median and interquartile range (IQR). The Kruskal-Wallis, Mann-Whitney U- 
test, or Fisher exact tests were used based on the results. In addition, Bonferroni correction was used for multiple testing on acute and post-COVID clinical manifestations.

To summarize the diverse information of frequencies of post-COVID manifestations, a meta-analysis approach was employed using Metafor R package (http://www.jstatsoft.org/v36/i03/). The logit transformed proportion was used to derive the weighted proportion. The overall pooled prevalence and $95 \%$ confidence intervals (Cls) were obtained using a random effect model for each clinical manifestation. Statistical heterogeneity between studies was evaluated by Cochran's Q-statistic, as well as $\operatorname{Tau}^{2}$ and $I^{2}$ statistics. A P value $>0.10$ in $Q$ statistics or $<50 \%$ in $P^{2}$ statistic indicated a lack of heterogeneity.

Next, we aimed to evaluate the likely influence of autonomic symptoms in severity of PCS, and their association with clinical phenotypes. Thus, a K-means clustering analysis based on the algorithm of Hartigan and Wong on weighted COMPASS 31 domains was conducted [20]. Shortly, the K-means method, aims to partition the points into $k$ groups such that the sum of squares from points to the assigned cluster centers is minimized. For this analysis, 25 random sets were used, and a final optimal number of clusters were obtained based on the average silhouette width. In addition, patients were evaluated based on their clinical status during acute COVID-19. The significance level of the study was set to 0.05 . Statistical analyses were done using $R$ software version 4.0.2. 


\section{Results}

\subsection{General characteristics}

General characteristics of patients are shown in Table 1. Out of a total of 100 patients, 53 were women, the median age was 49 years (IQR: 37.8 to 55.3 ), the median of post-COVID time was 219 days (IQR: 143 to 258), and 65 patients were hospitalized during the acute COVID-19. Constitutional symptoms, musculoskeletal and respiratory symptoms, ageusia and anosmia were the most frequent clinical manifestations registered during the acute illness (Table 1).

\subsection{Post-COVID manifestations}

Musculoskeletal, digestive (i.e., diarrhea) and neurological symptoms including depression (35\%) were the most frequent observed during PCS (Table 1 - Figure 2 A-B). One-third of PCS patients present with at least one musculoskeletal, respiratory, gastrointestinal and neurological symptoms simultaneously (Figure 2C). Interestingly, there were a reduction in the frequency of some acute symptoms reported by patients. However, arthralgia and diarrhea persisted in more than $40 \%$ of the patients during PCS (Figure 2D).

A median of anti-SARS-CoV-2 antibodies of $866.2 \mathrm{U} / \mathrm{mL}$ (IQR: 238.2 to 1681) was observed, indicating large inter-individual variability (Table 1). Despite this variability, almost all patients (98.0\%) presented positivity for anti-SARS-CoV-2 
antibodies (value of $\geq 0.80 \mathrm{U} / \mathrm{mL}$, Figure 3), of whom 88 patients disclosed titles above $151.4 \mathrm{U} / \mathrm{mL}$.

Evaluation of PCS based on severity of acute illness showed that hospitalized and critically ill patients were older, more likely to exhibit elevated body mass index, higher frequency of hypertension, fatigue, and fever on admission that ambulatory patients (Table 2). Noteworthy, during the PCS a previous hospitalization was not associated with any clinical manifestation. The levels of antibodies anti-SARSCoV-2 were lower in patients who were not previously hospitalized (Table 2). However, ambulatory patients were evaluated in earlier phases of PCS than hospitalized and critically ill patients (Kruskal-Wallis test, $\mathrm{P}<0.0001$ ).

\subsection{Post-COVID systematic review}

Initially, 1222 records were found through the database search. After duplicate studies were excluded, a total of 1208 studies were obtained. After the first records were screened by title and abstract, 42 articles were fully assessed for eligibility. Of these, 2 articles were excluded, since they reported PCS clinical manifestations but not patient data. This procedure left 40 articles (11,196 patients) that fulfilled the inclusion criteria, and they were included in the quantitative and qualitative synthesis (Figure 1 and Supplementary Material 2)

\subsection{Studies characteristics}


Out of 40 studies included in the systematic review [7,10,21-58], 30 were cohort studies, 5 cross-sectional, 3 case series, and 2 case-control studies. No clinical trials were included in the systematic review and meta-analysis.

\subsection{Post-COVID meta-analysis}

Pooled prevalence of PCS manifestations is summarized in Table 3. Fatigue/muscle weakness, dyspnea, pain and discomfort, anxiety/depression and impaired concentration were presented in more than $20 \%$ of patients included in the meta-analysis (Figure 4). These symptoms were reported in more than five manuscripts in the literature review. In addition, high methodological and statistical heterogeneity was found in this analysis, accounting for most of the imprecision detected by the $Q$ and $l^{2}$ statistics.

\subsection{Autonomic clusters in post-COVID syndrome}

Based on autonomic symptoms (by COMPASS 31) two clusters were obtained (Table 4 - Figure 5A). Impaired visual acuity and blurry vision were more frequently registered during the acute phase in patients belonging to cluster 2 that cluster 1 (Figure 5B), while depression, chills, weakness, diarrhea, musculoskeletal, palpitations/tachycardia, dryness, cognitive involvement, headache, dizziness, and tinnitus were more frequently observed in the postCOVID cluster 2 (Figure 5C). As expected, COMPASS 31 score was higher in cluster 2 than in cluster 1, as were the median Zung scores. Levels of antibodies were not different between clusters (Table 4). 


\section{Discussion}

This study indicates that a significant number of patients present with a clinical spectrum after SARS-CoV-2 infection recovery, affecting the quality of life and requiring interdisciplinary approach. Although the cases series do not evaluate incidence nor prevalence, musculoskeletal, digestive (i.e., diarrhea) and neurological symptoms including depression were the most frequent observed in our PCS patients. Arthralgia and diarrhea were the two more frequent acute clinical manifestations persisting during the PCS. Our results were consistent with the meta-analysis in which fatigue/muscle weakness, dyspnea, pain and discomfort, anxiety/depression and impaired concentration were presented in more than $20 \%$ of patients. Noteworthy, PCS was independent of severity of acute illness and the humoral response to RBD SARS-CoV-2.

The causes of PCS are under study, however the main hypotheses include a persisting chronic inflammatory process, an autoimmune phenomenon or even a hormonal imbalance as a consequence of an alteration in the hypothalamicpituitary-adrenal axis [59]. In this line, a study on COVID-19 patients at 3-6 months of convalescence showed that patients with PCS exhibit high levels of $\mathrm{CD}^{-} 7^{-} \lg \mathrm{D}^{-}$ B cells (which have been associated with autoimmune diseases such as multiple sclerosis [60]), CD8+ T cells, as well as elevated production of Th1 and Th17 cytokines, thus favoring a hyperinflammatory milieu. In addition, patients showed B cell impaired response given by IL-6/IL-10 imbalance [61]. In a similar study, 
convalescent patients yielded high levels of tumor necrosis factor (TNF) and IL-1 $\beta$ [62]. Recovered patients showed high levels of endothelial activation markers and pro-inflammatory mediators such as growth factors platelet-derived growth factor, vascular endothelial growth factor, MIP-1ß, eotaxin, IL-12p70, and IL-17A [63]. Thus, suggesting that clinical manifestations in PCS could be associated to persistence of a pro-inflammatory profile induced by COVID-19 during acute illness. In addition, this may suggest therapeutic targets for the specific management of PCS, including TNF blockade or immunomodulatory drugs.

Based on autonomic symptoms (by COMPASS 31) two clusters were obtained with different clinical characteristics. Cluster 2 exhibited high scores of COMPASS 31. This accounted for the $31 \%$ of all patients included (median COMPASS 31 score 22), suggesting that one-third of patients with PCS may yield higher scores when compared with the general population [64]. Interestingly, patients with higher scores exhibited more clinical manifestations and depression. These clusters may have therapeutic implications since clinicians should be aware of particular manifestations during the follow-up, and early psychosocial intervention may reduce the burden of PCS.

Persistence of symptoms has been evaluated in PCS. Moreno-Perez et al. [65], reported that up to $50.9 \%$ of the patients considered "recovered" persisted with symptoms similar to those experienced during the acute phase. Moreover, other studies showed that the reported duration of musculoskeletal symptoms varies widely depending on duration of patients follow-up [35,66-68]. Different protocols 
and populations as well as the preexistence of musculoskeletal symptoms, which were not evaluated in all the studies, preclude a comparative analysis. Nevertheless, early identification would allow to focus the therapeutic management of these patients [69].

Persistent elevation of IL-6 levels, an increase of the angiotensin-converting enzyme 2 in the peripheral nervous system and mast cell participation have been considered to explain the musculoskeletal symptoms in PCS [70-72]. Similarly, over-activation of nociceptive neurons, secondary to neurotropism of the virus, may cause prolongation of symptoms [73]. It is possible that most of the inflammatory response caused by the virus affects the integrity of the central and peripheral nervous system, which promotes the perpetuation of pain after the acute illness [74]. On the other hand, inflammatory damage, triggered by acute infection, would cause psychiatric disorders in predisposed individuals. These symptoms include depression, anxiety and, in worse situations, suicidal behavior [75].

Autonomic dysfunction was confirmed in our study. Orthostatic symptoms and hyperhidrosis have been described [56]. To date, it is unknown if a pre-existing history of minor autonomic symptoms may have some type of relation with autonomic disorders in PCS [76]. These results are relevant since disorders such as postural orthostatic tachycardia syndrome (POTS) and other autonomic dysfunctions may emerge after infectious triggers such as SARS-CoV-2 [77-81]. 
The mechanisms behind autonomic dysfunction are not clear. However, autoimmune phenomena could be associated with its appearance [82]. Production of autoantibodies against $\alpha 1, \beta 1$ and $\beta 2$ receptors, angiotensin II receptor type 1 , opioids 1, acetylcholine, M2 and M4S receptors are associated with development of POTS [36,83-85]. This immune mechanism, secondary to SARS-CoV2, could be triggered through molecular mimicry between antigens of autonomic nerve fibers, autonomic ganglia, and SARS-CoV2 antigens, as described in some autoimmune conditions.

Respiratory symptoms in PCS are common. The meta-analysis indicated that up to $48 \%$ of patients with PCS persisted with respiratory symptoms. Some studies have shown the persistence of pulmonary radiological and functional changes after acute infection [53]. Among the main respiratory functional changes, alteration in gas transfer measured by diffusing capacity for carbon monoxide ( $\left.D_{\text {LCo }}\right)$ has been documented up to 12 weeks of follow-up [13,86-88]. D Lco alteration could be associated with interstitial and vascular damage, secondary to acute infection $[89,90]$. These features may depend on the severity of the disease during the acute COVID-19 [91-93]. Pulmonary radiological alterations have been documented after 12 months post-infection [53].

Some symptoms during acute COVID-19 have been reported to be predictors of PCS, including diarrhea, anosmia, dyspnea, pleurisy, skin sensitivity, and A blood type [15]. A lower SARS-CoV-2 IgG titer at the beginning of the observation period was associated with a higher frequency of PCS [94]. Severity of acute COVID-19 
suggests that convalescent critically ill patients commonly experience long-lasting mental health illness. Anxiety, depression, post-traumatic stress disorder, memory and attention disorders are common [95]. However, in our case series severity of acute disease was not associated with PCS.

As expected, the levels of anti-SARS-CoV2 antibodies were lower in patients who were not previously hospitalized [96]. Our results confirm the heterogeneous but long-lasting humoral response to SARS-CoV-2 infection $[97,98]$. Other mechanisms beyond the humoral immune response can influence the persistence and/or triggering of PCS, such as viral shedding, therapy, clinical management, immune response, social isolation, comorbidities, age, sex, among others [54]. In terms of viral shedding, some studies have shown that persistent fragments of viral genes, including in feces though not infectious, could induce a hyperimmune response that explaining the persistence of symptoms in post-COVID patients $[99,100]$. Moreover, even if the virus is cleared, and there are high neutralizing antibody titers, the immune system could continue to be overactive, thus inducing PCS [99].

\section{Conclusions}

PCS is mainly characterized by musculoskeletal, pulmonary, digestive and neurological involvement including depression. PCS is independent of severity of acute illness and humoral response. Our study confirms the long-term immunity for SARS-CoV-2 but also the inter-individual variability of the immune response. 
Future studies should evaluate the mechanisms by which SARS-CoV-2 may cause PCS and the best therapeutic options.

\section{Post-COVID study group}

Ana María Vargas Suaza, Andrés Mauricio, Palomino Ríos, Carlos Andrés Moya Ortiz, Daniel Fernando Rangel Vera, Diana Carolina Guzmán Núñez, Estefanía Sanabria Medina, Gloria Sofía Guerrero Alvarez, Isabella Casallas Gutiérrez, Isabella Gracia Concha, Isabella Hernández Duarte, Jaime Andrés Antolinez Báez, José Manuel Fernández Rengifo, Jose Manuel Palacio Cardona, Juan Sebastián Beltrán, Julián Francisco Mora Jácome, Laura Zárate Pinzón, María Alejandra Garzón Parra, María Alejandra Melo, Maria Alejandra Muñoz Bernal, María Camila Ayala, María Paula Casanova, María Paula Espitia Correa, Marian Andrea Ochoa Patarroyo, Nicolás Aguirre Correal, Paola Saboya Galindo, Paula Andrea Monje,

Santiago Noriega Ramírez, Sara Juliana Guerrero León, Sofía Ballesteros Barreto, Valentina Fragala.

\section{Declaration of competing interest}

None.

\section{Funding}

The study was supported by grants from Universidad del Rosario (ABN011).

\section{Role of the Funder/Sponsor}


The funders had no role in the design and conduct of the study, collection, management, analysis, and interpretation of the data; preparation, review, or approval of the manuscript; and decision to submit the manuscript for publication.

\section{Acknowledgments}

The authors would like to thank all the members of the CREA and Elizabeth T. Cirulli for their contributions and fruitful discussions during the preparation of the manuscript.

\section{References}

[1] National Institute for Health and Care Excellence. COVID-19 rapid guideline: managing the long-term effects of COVID-19. NICE Guid 2021.

[2] Acosta-Ampudia Y, Monsalve DM, Rojas M, Rodríguez Y, Gallo JE, SalazarUribe JC, et al. COVID-19 convalescent plasma composition and immunological effects in severe patients. J Autoimmun 2021;118:102598. https://doi.org/10.1016/j.jaut.2021.102598.

[3] Guan W, Ni Z, Hu Y, Liang W, Ou C, He J, et al. Clinical Characteristics of Coronavirus Disease 2019 in China. N Engl J Med 2020;382:1708-20. https://doi.org/10.1056/NEJMoa2002032.

[4] Sandra Lopez-Leon, Talia Wegman-Ostrosky, Carol Perelman, Rosalinda Sepulveda, Paulina A Rebolledo, Angelica Cuapio SV. More than 50 Longterm effects of COVID-19: a systematic review and meta-analysis. MedRxiv 2021. https://doi.org/10.1101/2021.01.27.21250617.

[5] Goyal P, Choi JJ, Pinheiro LC, Schenck EJ, Chen R, Jabri A, et al. Clinical Characteristics of Covid-19 in New York City. N Engl J Med 2020;382:2372- 
4. https://doi.org/10.1056/NEJMc2010419.

[6] Sudre C, Murray B, Varsavsky T, Graham M, Penfold R, Bowyer R, et al. Attributes and predictors of Long-COVID: analysis of COVID cases and their symptoms collected by the Covid Symptoms Study App. BMJ 2020;In press. https://doi.org/https://doi.org/10.1101/2020.10.19.20214494.

[7] Garrigues E, Janvier P, Kherabi Y, Le Bot A, Hamon A, Gouze H, et al. Postdischarge persistent symptoms and health-related quality of life after hospitalization for COVID-19. J Infect 2020;81:e4-6. https://doi.org/10.1016/j.jinf.2020.08.029.

[8] Ayoubkhani D, Khunti K, Nafilyan V, Maddox T, Humberstone B, Diamond I, et al. Post-covid syndrome in individuals admitted to hospital with covid-19: retrospective cohort study. BMJ 2021:n693.

https://doi.org/10.1136/bmj.n693.

[9] Giannis D, Allen SL, Tsang J, Flint S, Pinhasov T, Williams S, et al. Postdischarge thromboembolic outcomes and mortality of hospitalized patients with COVID-19: the CORE-19 registry. Blood 2021;137:2838-47. https://doi.org/10.1182/blood.2020010529.

[10] Kamal M, Abo Omirah M, Hussein A, Saeed H. Assessment and characterisation of post-COVID-19 manifestations. Int J Clin Pract 2021;75. https://doi.org/10.1111/ijcp.13746.

[11] Vicente Herrero MT, Delgado Bueno S, Bandrés Moyá F, Ramírez Iñiguez de la Torre MV, Capdevila García L. Valoración del dolor. Revisión Comparativa de Escalas y Cuestionarios. Rev La Soc Española Del Dolor 2018. https://doi.org/10.20986/resed.2018.3632/2017. 
[12] GeCo Group. Towards a cooperative construction of questionnaires for Covid-19 host genetics initiative. Politec Di Milan, Italy 2020.

[13] Guler SA, Ebner L, Aubry-Beigelman C, Bridevaux P-O, Brutsche M, Clarenbach $\mathrm{C}$, et al. Pulmonary function and radiological features 4 months after COVID-19: first results from the national prospective observational Swiss COVID-19 lung study. Eur Respir J 2021;57. https://doi.org/10.1183/13993003.03690-2020.

[14] Zung WWK. A Self-Rating Depression Scale. Arch Gen Psychiatry 1965;12:63. https://doi.org/10.1001/archpsyc.1965.01720310065008.

[15] Cirulli ET, Schiabor Barrett KM, Riffle S, Bolze A, Neveux I, Dabe S, et al. Long-term COVID-19 symptoms in a large unselected population. MedRxiv 2020:2020.10.07.20208702. https://doi.org/10.1101/2020.10.07.20208702.

[16] Rojas M, Rodriguez Y, Pacheco Y, Zapata E, Monsalve DM, Mantilla RD, et al. Resilience in women with autoimmune rheumatic diseases. Jt Bone Spine 2018;85:715-20. https://doi.org/10.1016/j.jbspin.2017.12.012.

[17] Campo-Arias A, Díaz-Martínez LA, Rueda-Jaimes GE, Barros-Bermúdez JA. Validación de la escala de Zung para depresión en universitarias de Bucaramanga, Colombia . Rev Colomb Psiquiatr 2005;34:54-62.

[18] Sletten DM, Suarez GA, Low PA, Mandrekar J, Singer W. COMPASS 31: A Refined and Abbreviated Composite Autonomic Symptom Score. Mayo Clin Proc 2012;87:1196-201. https://doi.org/10.1016/j.mayocp.2012.10.013.

[19] Page MJ, Moher D, Bossuyt PM, Boutron I, Hoffmann TC, Mulrow CD, et al. PRISMA 2020 explanation and elaboration: updated guidance and exemplars for reporting systematic reviews. BMJ 2021;372:n160. 
https://doi.org/10.1136/bmj.n160.

[20] Hartigan JA, Wong MA. Algorithm AS 136: A K-Means Clustering Algorithm. Appl Stat 1979;28:100. https://doi.org/10.2307/2346830.

[21] Brandão Neto D, Fornazieri MA, Dib C, Di Francesco RC, Doty RL, Voegels $\mathrm{RL}$, et al. Chemosensory Dysfunction in COVID-19: Prevalences, Recovery Rates, and Clinical Associations on a Large Brazilian Sample. Otolaryngol Neck Surg 2021;164:512-8. https://doi.org/10.1177/0194599820954825.

[22] Santis LV-D, Sobrino B, González GE, Ruíz-Mesa JD, Plata A, MárquezGómez I, et al. Clinical and immunoserological status 12 weeks after infection with COVID-19: prospective observational study. MedRxiv 2020. https://doi.org/https://doi.org/10.1101/2020.10.06.20206060.

[23] Akter F, Mannan A, Mehedi HMH, Rob MA, Ahmed S, Salauddin A, et al. Clinical characteristics and short term outcomes after recovery from COVID19 in patients with and without diabetes in Bangladesh. Diabetes Metab Syndr Clin Res Rev 2020;14:2031-8.

https://doi.org/10.1016/j.dsx.2020.10.016.

[24] Goel N, Goyal N, Kumar R. Clinico-radiological evaluation of post COVID-19 at a tertiary pulmonary care centre in Delhi, India. Monaldi Arch Chest Dis 2021. https://doi.org/10.4081/monaldi.2021.1682.

[25] Alemanno F, Houdayer E, Parma A, Spina A, Del Forno A, Scatolini A, et al. COVID-19 cognitive deficits after respiratory assistance in the subacute phase: A COVID-rehabilitation unit experience. PLoS One 2021;16:e0246590. https://doi.org/10.1371/journal.pone.0246590.

[26] Ordinola Navarro A, Cervantes-Bojalil J, Cobos Quevedo O de J, Avila 
Martínez A, Hernández-Jiménez CA, Pérez Álvarez E, et al. Decreased quality of life and spirometric alterations even after mild-moderate COVID-19.

Respir Med 2021;181:106391. https://doi.org/10.1016/j.rmed.2021.106391.

[27] Zhao Y, Shang Y, Song W, Li Q, Xie H, Xu Q, et al. Follow-up study of the pulmonary function and related physiological characteristics of COVID-19 survivors three months after recovery. EClinicalMedicine 2020;25:100463. https://doi.org/10.1016/j.eclinm.2020.100463.

[28] Woo MS, Malsy J, Pöttgen J, Seddiq Zai S, Ufer F, Hadjilaou A, et al. Frequent neurocognitive deficits after recovery from mild COVID-19. Brain Commun 2020;2. https://doi.org/10.1093/braincomms/fcaa205.

[29] Wallukat G, Hohberger B, Wenzel K, Fürst J, Schulze-Rothe S, Wallukat A, et al. Functional autoantibodies against G-protein coupled receptors in patients with persistent Long-COVID-19 symptoms. J Transl Autoimmun 2021;4:100100. https://doi.org/10.1016/j.jtauto.2021.100100.

[30] Skala M, Svoboda M, Kopecky M, Kocova E, Hyrsl M, Homolac M, et al. Heterogeneity of post-COVID impairment: interim analysis of a prospective study from Czechia. Virol J 2021;18:73. https://doi.org/10.1186/s12985-02101546-8.

[31] Osikomaiya B, Erinoso O, Wright KO, Odusola AO, Thomas B, Adeyemi O, et al. 'Long COVID': persistent COVID-19 symptoms in survivors managed in Lagos State, Nigeria. BMC Infect Dis $2021 ; 21: 304$. https://doi.org/10.1186/s12879-020-05716-x.

[32] Arjmand P, Murtaza F, Eshtiaghi A, Popovic MM, Kertes PJ, Eng KT. Impact of the COVID-19 pandemic on characteristics of retinal detachments: the 
Canadian experience. Can J Ophthalmol 2021;56:88-95.

https://doi.org/10.1016/j.jcjo.2020.12.008.

[33] Needham E, Newcombe V, Michell A, Thornton R, Grainger A, Anwar F, et al. Mononeuritis multiplex: an unexpectedly frequent feature of severe COVID-19. J Neurol 2020;In press. https://doi.org/10.1007/s00415-02010321-8.

[34] Dennis A, Wamil M, Alberts J, Oben J, Cuthbertson DJ, Wootton D, et al. Multiorgan impairment in low-risk individuals with post-COVID-19 syndrome: a prospective, community-based study. BMJ 2021;11. https://doi.org/10.1136 / bmjopen-2020-048391.

[35] Fernández-de-las-Peñas C, Rodríguez-Jiménez J, Fuensalida-Novo S, Palacios-Ceña M, Gómez-Mayordomo V, Florencio LL, et al. Myalgia as a symptom at hospital admission by severe acute respiratory syndrome coronavirus 2 infection is associated with persistent musculoskeletal pain as long-term post-COVID sequelae. Pain 2021 ; In press.

https://doi.org/10.1097/j.pain.0000000000002306.

[36] Gambini G, Savastano MC, Savastano A, De Vico U, Crincoli E, Cozzupoli GM, et al. Ocular Surface Impairment After Coronavirus Disease 2019: A Cohort Study. Cornea 2021;40:477-83. https://doi.org/10.1097/ICO.0000000000002643.

[37] Klein H, Asseo K, Karni N, Benjamini Y, Nir-Paz R, Muszkat M, et al. Onset, duration and unresolved symptoms, including smell and taste changes, in mild COVID-19 infection: a cohort study in Israeli patients. Clin Microbiol Infect 2021;27:769-74. https://doi.org/10.1016/j.cmi.2021.02.008. 
[38] Leta V, Rodríguez-Violante M, Abundes A, Rukavina K, Teo JT, Falup-Pecurariu C, et al. Parkinson's Disease and Post-COVID-19 Syndrome: The Parkinson's Long-COVID Spectrum. Mov Disord 2021:mds.28622. https://doi.org/10.1002/mds.28622.

[39] Savastano A, Crincoli E, Savastano M, Younis S, Gambini G, De Vico U, et al. Peripapillary Retinal Vascular Involvement in Early Post-COVID-19 Patients. J Clin Med 2020;9:2895. https://doi.org/10.3390/jcm9092895.

[40] Townsend L, Dyer AH, Jones K, Dunne J, Mooney A, Gaffney F, et al. Persistent fatigue following SARS-CoV-2 infection is common and independent of severity of initial infection. PLoS One 2020;15:e0240784. https://doi.org/10.1371/journal.pone.0240784.

[41] Gaber TA-ZK, Ashish A, Unsworth A. Persistent post-covid symptoms in healthcare workers. Occup Med (Chic III) 2021; In press. https://doi.org/10.1093/occmed/kqab043.

[42] Mandal S, Barnett J, Brill SE, Brown JS, Denneny EK, Hare SS, et al. 'LongCOVID': a cross-sectional study of persisting symptoms, biomarker and imaging abnormalities following hospitalisation for COVID-19. Thorax 2021;76:396-8. https://doi.org/10.1136/thoraxjnl-2020-215818.

[43] Stavem K, Ghanima W, Olsen MK, Gilboe HM, Einvik G. Persistent symptoms 1.5-6 months after COVID-19 in non-hospitalised subjects: a population-based cohort study. Thorax 2021;76:405-7. https://doi.org/10.1136/thoraxjnl-2020-216377.

[44] Goërtz YMJ, Van Herck M, Delbressine JM, Vaes AW, Meys R, Machado FVC, et al. Persistent symptoms 3 months after a SARS-CoV-2 infection: the 
post-COVID-19 syndrome? ERJ Open Res 2020;6:00542-2020.

https://doi.org/10.1183/23120541.00542-2020.

[45] Leth S, Gunst JD, Mathiasen V, Hansen K, Søgaard O, Østergaard L, et al. Persistent Symptoms in Patients Recovering From COVID-19 in Denmark. Open Forum Infect Dis 2021;8. https://doi.org/10.1093/ofid/ofab042.

[46] Sykes DL, Holdsworth L, Jawad N, Gunasekera P, Morice AH, Crooks MG. Post-COVID-19 Symptom Burden: What is Long-COVID and How Should We Manage It? Lung 2021;199:113-9. https://doi.org/10.1007/s00408-02100423-z.

[47] Mahmud R, Rahman MM, Rassel MA, Monayem FB, Sayeed SKJB, Islam MS, et al. Post-COVID-19 syndrome among symptomatic COVID-19 patients: A prospective cohort study in a tertiary care center of Bangladesh. PLoS One 2021;16:e0249644. https://doi.org/10.1371/journal.pone.0249644.

[48] Halpin SJ, Mclvor C, Whyatt G, Adams A, Harvey O, McLean L, et al. Postdischarge symptoms and rehabilitation needs in survivors of COVID-19 infection: A cross-sectional evaluation. J Med Virol 2021;93:1013-22. https://doi.org/10.1002/jmv.26368.

[49] Simani L, Ramezani M, Darazam IA, Sagharichi M, Aalipour MA, Ghorbani F, et al. Prevalence and correlates of chronic fatigue syndrome and posttraumatic stress disorder after the outbreak of the COVID-19. J Neurovirol 2021;27:154-9. https://doi.org/10.1007/s13365-021-00949-1.

[50] Savastano MC, Gambini G, Cozzupoli GM, Crincoli E, Savastano A, De Vico U, et al. Retinal capillary involvement in early post-COVID-19 patients: a healthy controlled study. Graefe's Arch Clin Exp Ophthalmol 2021;In press. 
https://doi.org/10.1007/s00417-020-05070-3.

[51] Iqbal A, lqbal K, Arshad Ali S, Azim D, Farid E, Baig MD, et al. The COVID19 Sequelae: A Cross-Sectional Evaluation of Post-recovery Symptoms and the Need for Rehabilitation of COVID-19 Survivors. Cureus 2021;In press. https://doi.org/10.7759/cureus.13080.

[52] Islam MS, Ferdous MZ, Islam US, Mosaddek ASM, Potenza MN, Pardhan S. Treatment, Persistent Symptoms, and Depression in People Infected with COVID-19 in Bangladesh. Int J Environ Res Public Health 2021;18:1453. https://doi.org/10.3390/ijerph18041453.

[53] Wu X, Liu X, Zhou Y, Yu H, Li R, Zhan Q, et al. 3-month, 6-month, 9-month, and 12-month respiratory outcomes in patients following COVID-19-related hospitalisation: a prospective study. Lancet Respir Med 2021. https://doi.org/10.1016/S2213-2600(21)00174-0.

[54] Huang C, Huang L, Wang Y, Li X, Ren L, Gu X, et al. 6-month consequences of COVID-19 in patients discharged from hospital: a cohort study. Lancet 2021;397:220-32. https://doi.org/10.1016/S0140-6736(20)32656-8.

[55] Gallus R, Melis A, Rizzo D, Piras A, De Luca LM, Tramaloni P, et al. Audiovestibular symptoms and sequelae in COVID-19 patients. J Vestib Res 2021;In press:1-7. https://doi.org/10.3233/VES-201505.

[56] Shouman K, Vanichkachorn G, Cheshire WP, Suarez MD, Shelly S, Lamotte GJ, et al. Autonomic dysfunction following COVID-19 infection: an early experience. Clin Auton Res 2021;In press. https://doi.org/10.1007/s10286021-00803-8.

[57] Huang L, Zhao P, Tang D, Zhu T, Han R, Zhan C, et al. Cardiac Involvement 
in Patients Recovered From COVID-2019 Identified Using Magnetic

Resonance Imaging. JACC Cardiovasc Imaging 2020;13:2330-9.

https://doi.org/10.1016/j.jcmg.2020.05.004.

[58] Sonnweber T, Sahanic S, Pizzini A, Luger A, Schwabl C, Sonnweber B, et al. Cardiopulmonary recovery after COVID-19: an observational prospective multicentre trial. Eur Respir J 2021;57:2003481.

https://doi.org/10.1183/13993003.03481-2020.

[59] Klok FA, Kruip MJHA, van der Meer NJM, Arbous MS, Gommers DAMPJ, Kant KM, et al. Incidence of thrombotic complications in critically ill ICU patients with COVID-19. Thromb Res 2020;191:145-7. https://doi.org/10.1016/j.thromres.2020.04.013.

[60] Fraussen J, Marquez S, Takata K, Beckers L, Montes Diaz G, Zografou C, et al. Phenotypic and Ig Repertoire Analyses Indicate a Common Origin of IgD - CD27 - Double Negative B Cells in Healthy Individuals and Multiple Sclerosis Patients. J Immunol 2019;203:1650-64. https://doi.org/10.4049/jimmunol.1801236.

[61] Shuwa HA, Shaw TN, Knight SB, Wemyss K, McClure FA, Pearmain L, et al. Alterations in T and B cell function persist in convalescent COVID-19 patients. Med 2021. https://doi.org/10.1016/j.medj.2021.03.013.

[62] Talla A, Vasaikar S V, Lemos MP, Moodie Z, Pebworth M-PL, Henderson KE, et al. Longitudinal immune dynamics of mild COVID-19 define signatures of recovery and persistence. BioRxiv 2021. https://doi.org/10.1101/2021.05.26.442666.

[63] Ong SWX, Fong S-W, Young BE, Chan Y-H, Lee B, Amrun SN, et al. 
Persistent Symptoms and Association With Inflammatory Cytokine Signatures in Recovered Coronavirus Disease 2019 Patients. Open Forum Infect Dis 2021;8. https://doi.org/10.1093/ofid/ofab156.

[64] Rodríguez Y, Rojas M, Ramírez-Santana C, Acosta-Ampudia Y, Monsalve DM, Anaya J-M. Autonomic symptoms following Zika virus infection. Clin Auton Res 2018;28:211-4. https://doi.org/10.1007/s10286-018-0515-1.

[65] Moreno-Pérez O, Merino E, Leon-Ramirez J-M, Andres M, Ramos JM, Arenas-Jiménez J, et al. Post-acute COVID-19 syndrome. Incidence and risk factors: A Mediterranean cohort study. J Infect 2021;82:378-83. https://doi.org/10.1016/j.jinf.2021.01.004.

[66] Arnold DT, Hamilton FW, Milne A, Morley AJ, Viner J, Attwood M, et al. Patient outcomes after hospitalisation with COVID-19 and implications for follow-up: results from a prospective UK cohort. Thorax 2020;76:399-401. https://doi.org/10.1136/thoraxjnl-2020-216086.

[67] Carfì A, Bernabei R, Landi F. Persistent Symptoms in Patients After Acute COVID-19. JAMA 2020;324:603. https://doi.org/10.1001/jama.2020.12603.

[68] Jacobs LG, Gourna Paleoudis E, Lesky-Di Bari D, Nyirenda T, Friedman T, Gupta A, et al. Persistence of symptoms and quality of life at 35 days after hospitalization for COVID-19 infection. PLoS One 2020;15:e0243882. https://doi.org/10.1371/journal.pone.0243882.

[69] Kemp HI, Corner E, Colvin LA. Chronic pain after COVID-19: implications for rehabilitation. Br J Anaesth 2020;125:436-40. https://doi.org/10.1016/j.bja.2020.05.021.

[70] Mulchandani R, Lyngdoh T, Kakkar AK. Deciphering the COVID-19 cytokine 
storm: Systematic review and meta-analysis. Eur J Clin Invest 2021;51:e13429. https://doi.org/10.1111/eci.13429.

[71] Coomes EA, Haghbayan H. Interleukin-6 in Covid-19: A systematic review and meta-analysis. Rev Med Virol 2020;30:1-9.

https://doi.org/10.1002/rmv.2141.

[72] Shiers S, Ray PR, Wangzhou A, Sankaranarayanan I, Tatsui CE, Rhines LD, et al. ACE2 and SCARF expression in human dorsal root ganglion nociceptors: implications for SARS-CoV-2 virus neurological effects. Pain 2020;161:2494-501. https://doi.org/10.1097/j.pain.0000000000002051.

[73] McFarland AJ, Yousuf MS, Shiers S, Price TJ. Neurobiology of SARS-CoV-2 interactions with the peripheral nervous system: implications for COVID-19 and pain. PAIN Reports 2021;6:e885.

https://doi.org/10.1097/PR9.0000000000000885.

[74] Cohen SP, Baber ZB, Buvanendran A, McLean BC, Chen Y, Hooten WM, et al. Pain Management Best Practices from Multispecialty Organizations During the COVID-19 Pandemic and Public Health Crises. Pain Med 2020;21:1331-46. https://doi.org/10.1093/pm/pnaa127.

[75] Sher L. Post-COVID syndrome and suicide risk. QJM 2021;114:95-8. https://doi.org/10.1093/qjmed/hcab007.

[76] Blitshteyn S, Whitelaw S. Postural orthostatic tachycardia syndrome (POTS) and other autonomic disorders after COVID-19 infection: a case series of 20 patients. Immunol Res 2021;69:205-11. https://doi.org/10.1007/s12026-02109185-5.

[77] Thieben MJ, Sandroni P, Sletten DM, Benrud-Larson LM, Fealey RD, 
Vernino S, et al. Postural orthostatic tachycardia syndrome: the Mayo clinic experience. Mayo Clin Proc 2007;82:308-13.

https://doi.org/10.4065/82.3.308.

[78] Novak P. Post COVID-19 syndrome associated with orthostatic cerebral hypoperfusion syndrome, small fiber neuropathy and benefit of immunotherapy: a case report. ENeurologicalSci 2020;21:100276. https://doi.org/10.1016/j.ensci.2020.100276.

[79] Dani M, Dirksen A, Taraborrelli P, Torocastro M, Panagopoulos D, Sutton R, et al. Autonomic dysfunction in "long COVID": rationale, physiology and management strategies. Clin Med (Northfield II) 2021;21:e63-7. https://doi.org/10.7861/clinmed.2020-0896.

[80] Miglis MG, Prieto T, Shaik R, Muppidi S, Sinn D-I, Jaradeh S. A case report of postural tachycardia syndrome after COVID-19. Clin Auton Res 2020;30:449-51. https://doi.org/10.1007/s10286-020-00727-9.

[81] Kanjwal K, Jamal S, Kichloo A, Grubb BP. New-onset Postural Orthostatic Tachycardia Syndrome Following Coronavirus Disease 2019 Infection. J Innov Card Rhythm Manag 2020;11:4302-4. https://doi.org/10.19102/icrm.2020.111102.

[82] Blitshteyn S. Autoimmune markers and autoimmune disorders in patients with postural tachycardia syndrome (POTS). Lupus 2015;24:1364-9. https://doi.org/10.1177/0961203315587566.

[83] Yu X, Li H, Murphy TA, Nuss Z, Liles J, Liles C, et al. Angiotensin II Type 1 Receptor Autoantibodies in Postural Tachycardia Syndrome. J Am Heart Assoc 2018;7. https://doi.org/10.1161/JAHA.117.008351. 
[84] Watari M, Nakane S, Mukaino A, Nakajima M, Mori Y, Maeda Y, et al.

Autoimmune postural orthostatic tachycardia syndrome. Ann Clin Transl

Neurol 2018;5:486-92. https://doi.org/10.1002/acn3.524.

[85] Li H, Yu X, Liles C, Khan M, Vanderlinde-Wood M, Galloway A, et al.

Autoimmune basis for postural tachycardia syndrome. J Am Heart Assoc 2014;3:e000755. https://doi.org/10.1161/JAHA.113.000755.

[86] Mo X, Jian W, Su Z, Chen M, Peng H, Peng P, et al. Abnormal pulmonary function in COVID-19 patients at time of hospital discharge. Eur Respir J 2020;55. https://doi.org/10.1183/13993003.01217-2020.

[87] Qin W, Chen S, Zhang Y, Dong F, Zhang Z, Hu B, et al. Diffusion Capacity Abnormalities for Carbon Monoxide in Patients with COVID-19 At ThreeMonth Follow-up. Eur Respir J 2021. https://doi.org/10.1183/13993003.03677-2020.

[88] Shah AS, Wong AW, Hague CJ, Murphy DT, Johnston JC, Ryerson CJ, et al. A prospective study of 12-week respiratory outcomes in COVID-19-related hospitalisations. Thorax 2020;76:402-4. https://doi.org/10.1136/thoraxjnl2020-216308.

[89] Patel B V, Arachchillage DJ, Ridge CA, Bianchi P, Doyle JF, Garfield B, et al. Pulmonary Angiopathy in Severe COVID-19: Physiologic, Imaging, and Hematologic Observations. Am J Respir Crit Care Med 2020;202:690-9. https://doi.org/10.1164/rccm.202004-1412OC.

[90] Hanidziar D, Robson SC. Hyperoxia and modulation of pulmonary vascular and immune responses in COVID-19. Am J Physiol Lung Cell Mol Physiol 2021;320:L12-6. https://doi.org/10.1152/ajplung.00304.2020. 
[91] Moldofsky H, Patcai J. Chronic widespread musculoskeletal pain, fatigue, depression and disordered sleep in chronic post-SARS syndrome; a casecontrolled study. BMC Neurol 2011;11:37. https://doi.org/10.1186/14712377-11-37.

[92] Hui DS. Impact of severe acute respiratory syndrome (SARS) on pulmonary function, functional capacity and quality of life in a cohort of survivors. Thorax 2005;60:401-9. https://doi.org/10.1136/thx.2004.030205.

[93] Hui DS, Wong KT, Ko FW, Tam LS, Chan DP, Woo J, et al. The 1-year impact of severe acute respiratory syndrome on pulmonary function, exercise capacity, and quality of life in a cohort of survivors. Chest 2005;128:2247-61. https://doi.org/10.1378/chest.128.4.2247.

[94] Augustin M, Schommers P, Stecher M, Dewald F, Gieselmann L, Gruell H, et al. Post-COVID syndrome in non-hospitalised patients with COVID-19: a longitudinal prospective cohort study. Lancet Reg Heal Eur 2021;6:100122. https://doi.org/10.1016/j.lanepe.2021.100122.

[95] Hosey MM, Needham DM. Survivorship after COVID-19 ICU stay. Nat Rev Dis Prim 2020;6:60. https://doi.org/10.1038/s41572-020-0201-1.

[96] Okba NMA, Müller MA, Li W, Wang C, GeurtsvanKessel CH, Corman VM, et al. Severe Acute Respiratory Syndrome Coronavirus 2-Specific Antibody Responses in Coronavirus Disease Patients. Emerg Infect Dis 2020;26:1478-88. https://doi.org/10.3201/eid2607.200841.

[97] Dan JM, Mateus J, Kato Y, Hastie KM, Yu ED, Faliti CE, et al. Immunological memory to SARS-CoV-2 assessed for up to 8 months after infection. Science (80- ) 2021;371. https://doi.org/10.1126/science.abf4063. 
[98] Mazzoni A, Maggi L, Capone M, Vanni A, Spinicci M, Salvati L, et al. Heterogeneous magnitude of immunological memory to SARS-CoV-2 in recovered individuals. Clin Transl Immunol 2021;10:e1281. https://doi.org/10.1002/cti2.1281.

[99] Folgueira MD, Luczkowiak J, Lasala F, Pérez-Rivilla A, Delgado R. Prolonged SARS-CoV-2 cell culture replication in respiratory samples from patients with severe COVID-19. Clin Microbiol Infect 2021;27:886-91. https://doi.org/10.1016/j.cmi.2021.02.014.

[100] Salamanna F, Veronesi F, Martini L, Landini MP, Fini M. Post-COVID-19 Syndrome: The Persistent Symptoms at the Post-viral Stage of the Disease. A Systematic Review of the Current Data. Front Med 2021;8:653516. https://doi.org/10.3389/fmed.2021.653516. 
Table 1. General characteristics of 100 post-COVID patients.

\begin{tabular}{ll}
\hline Variable \\
Sex \\
Female \\
Male \\
Age (Median -IQR) \\
Body mass index (Median -IQR) \\
Post-COVID time (days, Median \\
Comorbidities (Prior COVID-19) \\
Hypertension \\
Type 2 diabetes \\
COPD \\
Cancer \\
Dyslipidemia \\
Kidney disease \\
Hypothyroidism \\
Asthma \\
Coronary artery disease \\
Clinical management
\end{tabular}

Clinical management

Hospitalization

Days of hospitalization (Median -IQR)

ICU

Days of ICU (Median -IQR)

\section{Acute COVID-19 symptoms}

Fatigue

Headache

Myalgia

Arthralgia

Fever

Dry cough

Dyspnea

Ageusia

Anosmia

Pharyngitis

Diarrhea

Dizziness

Rhinorrhea

Confusion

Vomiting

Blurry vision

Impaired visual acuity

Edema

Post-COVID manifestations

Arthralgia

Back pain

Arms/legs heaviness

Weakness

Diarrhea

Headache

Myalgia

Body pain

Paresthesia

Attention disorders

Memory disorders

Fatigue

\section{Post-COVID}

n: 100

$53(53.0 \%)$

$47(47.0 \%)$

49 (37.8 to 55.3 )

28.1 (25.1 to 30.4 )

219 days (143 to 258 )

$$
\begin{gathered}
17(17.0 \%) \\
15(15.0 \%) \\
1(1.0 \%) \\
1(1.0 \%) \\
12(12.0 \%) \\
3(3.0 \%) \\
12(12.0 \%) \\
0(0.0 \%) \\
0(0.0 \%)
\end{gathered}
$$

$65(65.0 \%)$

11 (7.5 to 16.5$)$

$24 / 65(36.9 \%)$

10 (6.5 to 14)

79 (79.0\%)

$67(67.0 \%)$

$66(66.0 \%)$

$62(62.0 \%)$

$62(62.0 \%)$

$61(61.0 \%)$

$59(59.0 \%)$

$53(53.0 \%)$

$51(51.0 \%)$

$48(48.0 \%)$

$40(40.0 \%)$

$35(35.0 \%)$

$34(34.0 \%)$

$21(21.0 \%)$

$19(19.0 \%)$

$18(18.0 \%)$

$13(13.0 \%)$

$10(10.0 \%)$

$65(65.0 \%)$

$55(55.0 \%)$

$47(47.0 \%)$

$46(46.0 \%)$

$46(46.0 \%)$

$45(45.0 \%)$

$42(42.0 \%)$

$40(40.0 \%)$

$38(38.0 \%)$

$36(36.0 \%)$

$36(36.0 \%)$

$34(34 \%)$ 


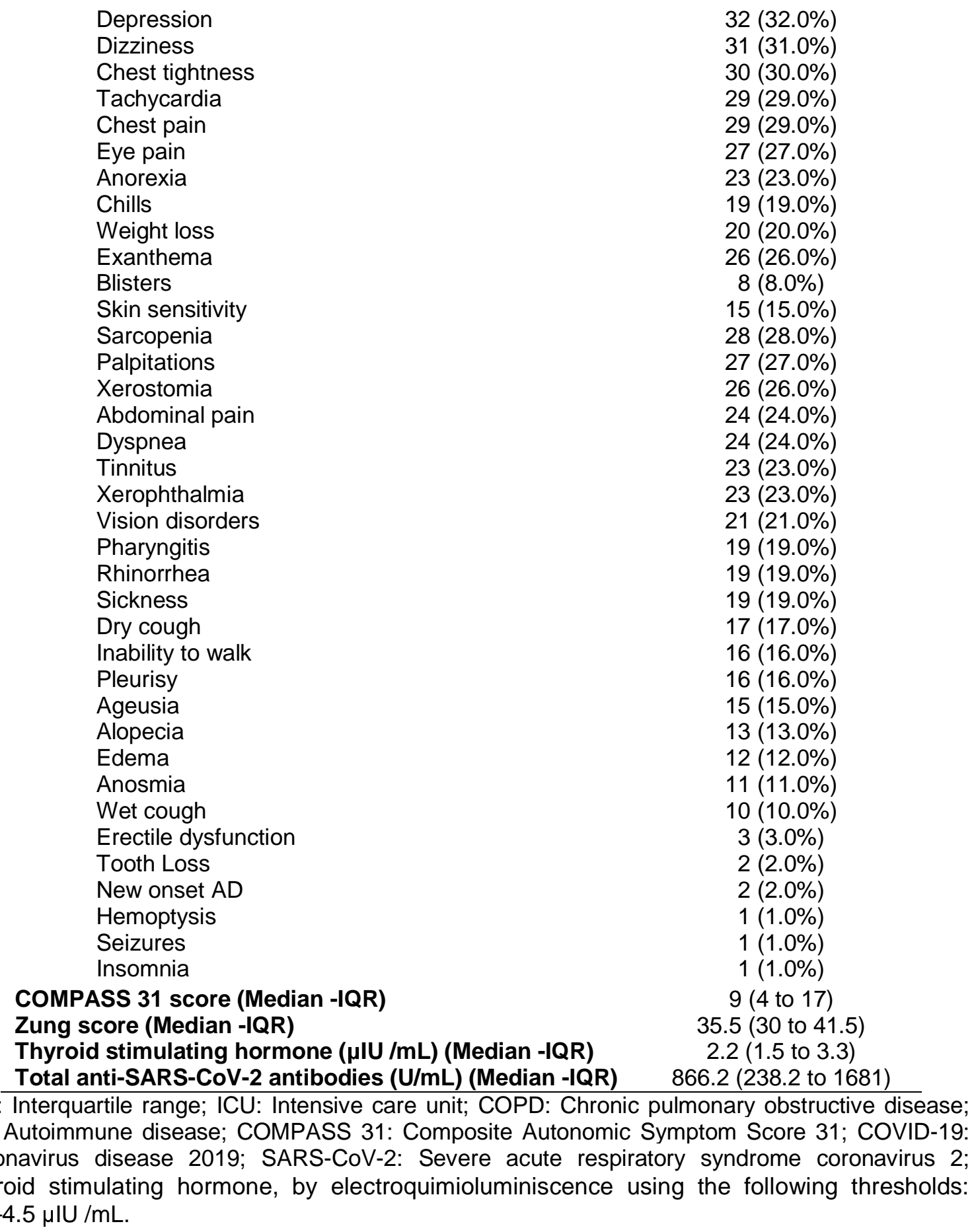


medRxiv preprint doi: https://doi.org/10.1101/2021.07.17.21260655; this version posted July $20,2021$. The copyright holder for this preprint (which was not certified by peer review) is the author/funder, who has granted medRxiv a license to display the preprint in perpetuity.

All rights reserved. No reuse allowed without permission.

Table 2. General characteristics of post-COVID patients based on severity of acute disease.

\begin{tabular}{|c|c|c|c|c|}
\hline Variable & $\begin{array}{l}\text { Ambulatory } \\
\mathrm{n}: 35\end{array}$ & $\begin{array}{c}\text { Severe disease } \\
n: 41\end{array}$ & $\begin{array}{c}\text { Critical disease } \\
\text { n: } 24\end{array}$ & P value \\
\hline Sex & & & & $<0.000^{\circ}$ \\
\hline Female & $30(85.7 \%)$ & $15(36.6 \%)$ & $8(33.3 \%)$ & \\
\hline Male & $5(14.3 \%)$ & $26(63.4 \%)$ & $16(66.7 \%)$ & \\
\hline Age (Median -IQR) & 41 (95.5 to 49.5$)$ & $51(44$ to 55$)$ & 52.5 (41.3 to 59.5$)$ & 0.0020 \\
\hline Body mass index (Median -IQR) & 25.4 (23.6 to 28.4$)$ & 28.8 (26 to 32$)$ & 28.3 (25.7 to 30.3$)$ & 0.0006 \\
\hline \multicolumn{4}{|l|}{ Comorbidities (Prior COVID-19) } & $<0.000$ \\
\hline Hypertension & $2(5.7 \%)$ & $8(19.5 \%)$ & $7(29.2 \%)$ & 0.0361 \\
\hline Type 2 diabetes & $2(5.7 \%)$ & $7(17.1 \%)$ & $6(25.0 \%)$ & 0.0943 \\
\hline COPD & $0(0.0 \%)$ & $1(2.4 \%)$ & $0(0.0 \%)$ & 1.0000 \\
\hline Cancer & $1(2.9 \%)$ & $0(0.0 \%)$ & $0(0.0 \%)$ & 0.5900 \\
\hline Dyslipidemia & $1(2.9 \%)$ & $6(14.6 \%)$ & $5(20.8 \%)$ & 0.0733 \\
\hline Kidney disease & $1(2.9 \%)$ & $1(2.4 \%)$ & $1(4.2 \%)$ & 1.0000 \\
\hline Hypothyroidism & $2(5.7 \%)$ & $8(19.5 \%)$ & $2(8.3 \%)$ & 0.1824 \\
\hline Asthma & $0(0.0 \%)$ & $0(0.0 \%)$ & $0(0.0 \%)$ & - \\
\hline Coronary artery disease & $0(0.0 \%)$ & $0(0.0 \%)$ & $0(0.0 \%)$ & - \\
\hline \multicolumn{5}{|l|}{ Acute COVID-19 symptoms } \\
\hline Anosmia & $20(57.1 \%)$ & $22(53.7 \%)$ & $9(37.5 \%)$ & 0.3156 \\
\hline Ageusia & 22 (62.9\%) & $22(53.7 \%)$ & $9(37.5 \%)$ & 0.1764 \\
\hline Fatigue & 19 (54.3\%) & 38 (92.7\%) & 22 (91.7\%) & $<0.0001$ \\
\hline Headache & $25(71.4 \%)$ & $28(68.3 \%)$ & $14(58.3 \%)$ & 0.5896 \\
\hline Dry cough & $16(45.7 \%)$ & $27(65.9 \%)$ & $18(75.0 \%)$ & 0.0580 \\
\hline Rhinorrhea & $12(34.3 \%)$ & $15(36.6 \%)$ & $7(29.2 \%)$ & 0.8301 \\
\hline Pharyngitis & 17 (48.6\%) & 20 (48.8\%) & $11(45.8 \%)$ & 1.0000 \\
\hline Dizziness & 11 (31.4\%) & $14(34.1 \%)$ & $10(41.7 \%)$ & 0.7186 \\
\hline Confusion & $5(14.3 \%)$ & $7(17.1 \%)$ & $9(37.5 \%)$ & 0.0916 \\
\hline Impaired visual acuity & $3(8.6 \%)$ & $8(19.5 \%)$ & $2(8.3 \%)$ & 0.3112 \\
\hline Blurry vision & $5(14.3 \%)$ & $11(26.8 \%)$ & $2(8.3 \%)$ & 0.1586 \\
\hline Dyspnea & $15(42.9 \%)$ & 27 (65.9\%) & $17(70.8 \%)$ & 0.0599 \\
\hline Diarrhea & $9(25.7 \%)$ & $23(56.1 \%)$ & $8(33.3 \%)$ & 0.0203 \\
\hline Vomiting & $4(11.4 \%)$ & $12(29.3 \%)$ & $3(12.5 \%)$ & 0.1161 \\
\hline Myalgia & $20(57.1 \%)$ & $32(78.0 \%)$ & $14(58.3 \%)$ & 0.1071 \\
\hline Arthralgia & $21(60.0 \%)$ & 27 (65.9\%) & $14(58.3 \%)$ & 0.7796 \\
\hline Edema & $5(14.3 \%)$ & $4(9.8 \%)$ & $1(4.2 \%)$ & 0.5328 \\
\hline Fever & $13(37.1 \%)$ & $30(73.2 \%)$ & $19(79.2 \%)$ & 0.0010 \\
\hline \multicolumn{5}{|l|}{ Post-COVID symptoms } \\
\hline Depression & $13(37.1 \%)$ & $8(19.5 \%)$ & $11(45.8 \%)$ & 0.0661 \\
\hline New onset $A D$ & $2(5.7 \%)$ & $0(0.0 \%)$ & $0(0.0 \%)$ & 0.1760 \\
\hline Anorexia & $9(25.7 \%)$ & $8(19.5 \%)$ & $6(25.0 \%)$ & 0.8272 \\
\hline Chills & 7 (20.0\%) & $8(19.5 \%)$ & $4(16.7 \%)$ & 1.0000 \\
\hline Weight Loss & $8(22.9 \%)$ & $6(14.6 \%)$ & $6(25.0 \%)$ & 0.5092 \\
\hline Exanthema & $9(25.7 \%)$ & $12(29.3 \%)$ & $5(20.8 \%)$ & 0.7705 \\
\hline Blisters & $4(11.4 \%)$ & $3(7.3 \%)$ & $1(4.2 \%)$ & 0.7217 \\
\hline Skin sensitivity & $8(22.9 \%)$ & 7 (17.1\%) & $0(0.0 \%)$ & 0.0347 \\
\hline Sarcopenia & $6(17.1 \%)$ & $11(26.8 \%)$ & $11(45.8 \%)$ & 0.0601 \\
\hline Weakness & $14(40.0 \%)$ & 15 (36.6\%) & 17 (70.8\%) & 0.0221 \\
\hline Myalgia & $14(40.0 \%)$ & $17(41.5 \%)$ & $11(45.8 \%)$ & 0.9333 \\
\hline Back pain & 15 (42.9\%) & $24(58.5 \%)$ & $16(66.7 \%)$ & 0.1752 \\
\hline Arms/legs heaviness & $12(34.3 \%)$ & $22(53.7 \%)$ & $13(54.2 \%)$ & 0.1825 \\
\hline Inability to walk & $3(8.6 \%)$ & $7(17.1 \%)$ & $6(25.0 \%)$ & 0.2323 \\
\hline Body pain & $10(28.6 \%)$ & $17(41.5 \%)$ & $13(54.2 \%)$ & 0.1420 \\
\hline Arthralgia & 20 (57.1\%) & $28(68.3 \%)$ & 17 (70.8\%) & 0.4965 \\
\hline
\end{tabular}




\begin{tabular}{|c|c|c|c|c|}
\hline Fatigue & $9(25.7 \%)$ & $15(36.6 \%)$ & $10(41.7 \%)$ & 0.4078 \\
\hline Palpitations & $9(25.7 \%)$ & $11(26.8 \%)$ & $7(29.2 \%)$ & 0.9593 \\
\hline Xerostomia & $9(25.7 \%)$ & $8(19.5 \%)$ & $9(37.5 \%)$ & 0.2800 \\
\hline Chest tightness & $9(25.7 \%)$ & $14(34.1 \%)$ & $7(29.2 \%)$ & 0.6980 \\
\hline Tachycardia & $10(28.6 \%)$ & $12(29.3 \%)$ & $7(29.2 \%)$ & 1.000 \\
\hline Edema & $5(14.3 \%)$ & $6(14.6 \%)$ & $1(4.2 \%)$ & 0.4584 \\
\hline Chest pain & $11(31.4 \%)$ & $11(26.8 \%)$ & $7(29.2 \%)$ & 0.9596 \\
\hline Hemoptysis & $1(2.9 \%)$ & $0(0.0 \%)$ & $0(0.0 \%)$ & 0.5900 \\
\hline Dyspnea & $11(31.4 \%)$ & 8 (19.5\%) & $5(20.8 \%)$ & 0.4587 \\
\hline Wet cough & $3(8.6 \%)$ & $4(9.8 \%)$ & $3(12.5 \%)$ & 0.8373 \\
\hline Dry cough & $4(11.4 \%)$ & $10(24.4 \%)$ & $3(12.5 \%)$ & $0.31 \varepsilon$ \\
\hline Pleurisy & 7 (20.0\%) & $6(14.6 \%)$ & $3(12.5 \%)$ & 0.737 \\
\hline Rhinorrhea & $3(8.6 \%)$ & 9 (22.0\%) & $7(29.2 \%)$ & 0.103 \\
\hline Sickness & $7(20.0 \%)$ & $10(24.4 \%)$ & $2(8.3 \%)$ & 0.286 \\
\hline Abdominal pain & $8(22.9 \%)$ & $11(26.8 \%)$ & $5(20.8 \%)$ & 0.871 \\
\hline Paresthesia & $11(31.4 \%)$ & $16(39.0 \%)$ & $11(45.8 \%)$ & 0.5271 \\
\hline Attention disorders & $13(37.1 \%)$ & 9 (22.0\%) & 14 (58.3\%) & 0.014 \\
\hline Memory disorders & $12(34.3 \%)$ & $9(22.0 \%)$ & $15(62.5 \%)$ & 0.0047 \\
\hline Seizures & $1(2.9 \%)$ & $0(0.0 \%)$ & $0(0.0 \%)$ & 0.590 \\
\hline Headache & 15 (42.9\%) & 18 (43.9\%) & 12 (50.0\%) & 0.873 \\
\hline Dizziness & $11(31.4 \%)$ & $12(29.3 \%)$ & 8 (33.3\%) & 0.961 \\
\hline Xerophthalmia & $6(17.1 \%)$ & $11(26.8 \%)$ & $6(25.0 \%)$ & 0.594 \\
\hline Tooth Loss & $1(2.9 \%)$ & $1(2.4 \%)$ & $0(0.0 \%)$ & 1.0000 \\
\hline Tinnitus & $10(28.6 \%)$ & 7 (17.1\%) & $6(25.0 \%)$ & 0.4914 \\
\hline Anosmia & 7 (20.0\%) & $3(7.3 \%)$ & $1(4.2 \%)$ & $0.15 \varepsilon$ \\
\hline Ageusia & $10(28.6 \%)$ & $3(7.3 \%)$ & $2(8.3 \%)$ & 0.036 \\
\hline Vision disorders & $4(11.4 \%)$ & $10(24.4 \%)$ & $7(29.2 \%)$ & 0.198 \\
\hline Eye pain & $7(20.0 \%)$ & $13(31.7 \%)$ & $7(29.2 \%)$ & $0.54 \varepsilon$ \\
\hline Pharyngitis & $4(11.4 \%)$ & $7(17.1 \%)$ & $8(33.3 \%)$ & 0.122 \\
\hline Alopecia & $5(14.3 \%)$ & $5(12.2 \%)$ & $3(12.5 \%)$ & 1.000 \\
\hline Erectile dysfunction & $0(0.0 \%)$ & $0(0.0 \%)$ & $3(12.5 \%)$ & 0.0125 \\
\hline Insomnia & $1(2.9 \%)$ & $0(0.0 \%)$ & $0(0.0 \%)$ & 0.5900 \\
\hline SS-31 score (Median -IQR) & $7(2.5$ to 16$)$ & $9(5$ to 17$)$ & $13(6.5$ to 17.5$)$ & 0.322 \\
\hline core (Median -IQR) & 36 (29.5 to 45) & 32 (29 to 38 ) & 38.5 (32.8 to 44.3 ) & 0.150 \\
\hline $\begin{array}{l}\text { d stimulating hormone }(\mu \mathrm{IU} / \mathrm{mL}) \\
\text { (n -IQR) }\end{array}$ & 1.90 (1.1 to 2.5$)$ & 2.66 (2.0 to 4.0$)$ & 2.06 (1.3 to 3.5$)$ & 0.013 \\
\hline $\begin{array}{l}\text { Inti-SARS-CoV-2 antibodies (U/mL) } \\
\text { in -IQR) }\end{array}$ & 200.2 (52.1 to 398.2) & $\begin{array}{c}1270(911.5 \text { to } \\
1941)\end{array}$ & $\begin{array}{l}1537.5(780.9 \text { to } \\
2500)\end{array}$ & $<0.00$ \\
\hline
\end{tabular}

IQR: Interquartile range; ICU: Intensive care unit; COPD: Chronic pulmonary obstructive disease; AD: Autoimmune disease; COMPASS 31: Composite Autonomic Symptom Score 31; COVID-19: Coronavirus disease 2019; SARS-CoV-2: Severe acute respiratory syndrome coronavirus 2; Thyroid stimulating hormone, by electroquimioluminiscence using the following thresholds: $0.3-4.5 \mu \mathrm{IU} / \mathrm{mL}$.

${ }^{a} \mathrm{P}$ values for categorical variables were obtained by Fisher's exact test. Quantitative variables were analyzed by Kruskal-Wallis test.

${ }^{\mathrm{b}}$ A linear regression model including total SARS-CoV-2 antibodies as dependent variable was conducted. Sex, age, body mass index, clinical management, and post-COVID time were included as covariates. Linear model confirmed that post-COVID time was a confounding factor for the difference of total SARS-CoV-2 antibodies among groups $(\beta=4.36, P=0.0126)$. In addition, significant interactions for ICU management confirmed this result $(\beta=-5.65, P=$ 0.0221).

* Statistically significant after Bonferroni correction. P value threshold for acute COVID-19 symptoms: $0.05 / 18=0.0028 ; P$ value threshold for post-COVID symptoms: $0.05 / 47=0.0011$. 
medRxiv preprint doi: https://doi.org/10.1101/2021.07.17.21260655; this version posted July 20, 2021. The copyright holder for this preprint (which was not certified by peer review) is the author/funder, who has granted medRxiv a license to display the preprint in perpetuity.

All rights reserved. No reuse allowed without permission.

Table 3. Clinical features of post-COVID-19 patients (systematic review and metaanalysis).

\begin{tabular}{|c|c|c|c|}
\hline \multirow{2}{*}{\multicolumn{4}{|c|}{ 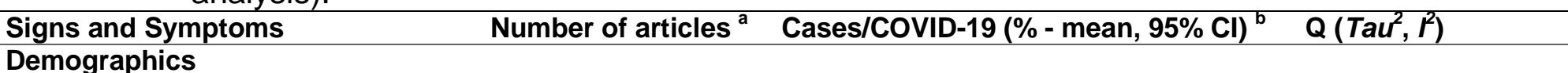 }} \\
\hline & & & \\
\hline & 40 & $5087 / 11196(50.0 \%, 44.5$ to 55.6$)$ & $<0.01(0.5,96.3)$ \\
\hline Age (years) & 34 & 10081 (50.2 years, 47.0 to 53.5 ) & $<0.01(90.0,99.4 \%)$ \\
\hline Time to follow-up (days) & 7 & 2849 (105.9 days, 89.1 to 122.7 ) & $<0.01(512.1,99.8 \%)$ \\
\hline \multicolumn{4}{|l|}{ Constitutional symptoms } \\
\hline Fever & 8 & $269 / 3064(9.1 \%, 2.7$ to 26.9$)$ & $<0.01(3.3,98.1 \%)$ \\
\hline Anorexia & 5 & $173 / 2183(8.0 \%, 6.9$ to 9.2$)$ & $0.77(0,0.0 \%)$ \\
\hline Weight loss & 3 & $82 / 2414(4.1 \%, 2.8$ to 5.9$)$ & $0.01(0.1,41.5 \%)$ \\
\hline Night sweats & 3 & $49 / 774(5.10 \%, 0.8$ to 26.6$)$ & $<0.01(2.7,96.4 \%)$ \\
\hline Asthenia & 2 & $49 / 126(20.9 \%, 2.1$ to 76.8$)$ & $0.01(2.9,83.9 \%)$ \\
\hline Heat intolerance/Flushing & 2 & $276 / 2140(10.0 \%, 3.6$ to 25.1$)$ & $0.18(0.4,43.5 \%)$ \\
\hline \multicolumn{4}{|l|}{ Neurological } \\
\hline Headache & 16 & $1365 / 7018(14.2 \%, 7.7$ to 24.6$)$ & $<0.01(1.8,98.5 \%)$ \\
\hline Cognitive impairment & 14 & $464 / 2991(14.8 \%, 6.1$ to 31.8$)$ & $<0.01(3.4,98.4 \%)$ \\
\hline Dizziness & 6 & $722 / 4912(14.2 \%, 2.5$ to 52.3$)$ & $<0.01(5.4,99.5 \%)$ \\
\hline Dementia & 3 & $89 / 405(12.4 \%, 4.3$ to 30.9$)$ & $<0.01(0.8,82.0 \%)$ \\
\hline Polyneuropathy & 3 & $5 / 69(8.3 \%, 3.5$ to 18.5$)$ & $0.5(0,0.0 \%)$ \\
\hline Dysautonomia & 2 & $11 / 58(16.9 \%, 4.0$ to 49.8$)$ & $0.1(1.0,73.8 \%)$ \\
\hline Inability to walk & 2 & $105 / 359(26.3 \%, 9.4$ to 55$)$ & $<0.01(0.8,95.7 \%)$ \\
\hline Stroke & 2 & $9 / 445(1.8 \%, 0.5$ to 6.6$)$ & $0.16(0.6,49.9 \%)$ \\
\hline Anomic aphasia & 2 & $7 / 49(14.9 \%, 3.2$ to 48.5$)$ & $0.06(1.1,72.5 \%)$ \\
\hline Tremor & 2 & $7 / 305(3.8 \%, 0.2$ to 48.9$)$ & $<0.01(5.0,93.0 \%)$ \\
\hline Syncope & 1 & $3 / 27(11.1 \%, 3.6$ to 29.3$)$ & NA \\
\hline Restless leg syndrome & 1 & $2 / 355(0.56 \%, 0.1$ to 2.2$)$ & NA \\
\hline Ataxia & 1 & $1 / 48(2.1 \%, 0.3$ to 13.4$)$ & NA \\
\hline Orthostatic headache & 1 & $6 / 27(22.2 \%, 10.3$ to 41.5$)$ & NA \\
\hline Paresthesia & 1 & $13 / 49(26.5 \%, 16.1$ to 40.5$)$ & NA \\
\hline Delirium & 1 & $2 / 27(7.4 \%, 1.9$ to 25.3$)$ & NA \\
\hline \multicolumn{4}{|l|}{ Ophthalmological } \\
\hline Blurry vision & 4 & $86 / 746(8.5 \%, 2.9$ to 22.1$)$ & $<0.01(1.1,93.5 \%)$ \\
\hline $\begin{array}{l}\text { Xeropthalmia/Sicca } \\
\text { symptoms }\end{array}$ & 3 & $42 / 171(14.1 \%, 2.7$ to 49.1$)$ & $<0.01(2.1,90.4 \%)$ \\
\hline Impaired visual acuity & 2 & $41 / 802(10.0 \%, 1.0$ to 56.3$)$ & $<0.01(3.1,98.0 \%)$ \\
\hline Conjunctivitis & 1 & $2 / 102(2.0 \%, 0.5$ to 7.5$)$ & NA \\
\hline Eye tearing & 1 & $2 / 64(3.1 \%, 0.8$ to 11.7$)$ & NA \\
\hline Macular detachment & 1 & $55 / 87(63.2 \%, 52.6$ to 72.7$)$ & NA \\
\hline Ocular burning sensation & 1 & $15 / 64(23.4 \%, 14.7$ to 35.3$)$ & NA \\
\hline Red eye & 1 & $2 / 64(3.1 \%, 0.8$ to 11.7$)$ & NA \\
\hline Retinal cotton wool spots & 1 & $9 / 70(12.9 \%, 6.8$ to 22.9$)$ & NA \\
\hline $\begin{array}{c}\text { Vitreous fibrillary } \\
\text { degeneration } \\
\text { Otorhinolaryngological }\end{array}$ & 1 & $10 / 70(14.3 \%, 7.9$ to 24.6$)$ & NA \\
\hline Ageusia & 13 & $707 / 6628(8.2 \%, 5.1$ to 12.8$)$ & $<0.01(0.7,96.4 \%)$ \\
\hline Anosmia & 17 & $926 / 7302(10.8 \%, 6.9$ to 16.5$)$ & $<0.01(1.0,97.4 \%)$ \\
\hline
\end{tabular}


medRxiv preprint doi: https://doi.org/10.1101/2021.07.17.21260655; this version posted July 20, 2021. The copyright holder for this preprint (which was not certified by peer review) is the author/funder, who has granted medRxiv a license to display the preprint in perpetuity.

All rights reserved. No reuse allowed without permission.

Sore throat 6

Nasal congestion $\quad 5$

Tinnitus

Sneezing/Coryza

Vertigo

Otalgia

Epistaxis

Hypoacusia

Laryngeal sensitivity

Nasal itching

Cold nose

Phonophobia

Dysphagia

Voice changes

Respiratory

Dyspnea

Cough

Pleuritic pain

Pulmonary fibrosis

Xerotrachea

Expectoration

Wheezing

Cardiovascular

Chest pain

Palpitations

Myocarditis

Arrhythmia

Bradycardia

Pericardial effusion

Gastrointestinal

Diarrhea/Vomiting

Nausea

Dyspepsia

Abdominal pain

Early satiety

\section{Genitourinary}

Urinary urgency

Urinary hesitancy

\section{Musculoskeletal}

Fatigue/Muscle weakness 25

Arthralgia/Myalgia 13

Pain and discomfort 5

Burning feet pain 2

Numbness

Back pain

\section{4}

2

2

1

1

1

1

1

1

1

1

1

23

17

2

2

1

1

1

13

7

3

2

2

1

9

4

3

1

1

1

1

25

2

1

1
$781 / 4504(11.9 \%, 3.4$ to 34.4$)$

$490 / 3373(8.0 \%, 1.9$ to 27.8$)$

$80 / 848(4.7 \%, 0.6$ to 27.5$)$

$290 / 2768(8.29 \%, 3.8$ to 17.3$)$

$11 / 629(1.8 \%, 0.9$ to 3.4$)$

$169 / 2113(8.0 \%, 6.9$ to 9.2$)$

$4 / 655(0.6 \%, 0.2$ to 1.6$)$

$1 / 48(2.1 \%, 0.3$ to 13.4$)$

$17 / 100(17.0 \%, 10.8$ to 25.7$)$

$30 / 655(4.6 \%, 3.2$ to 6.5$)$

$380 / 2113(18.0 \%, 16.4$ to 19.7$)$

$1 / 18(5.6 \%, 0.8$ to 30.7$)$

$8 / 100(8.0 \%, 4.1$ to 15.2$)$

$20 / 100(20.0 \%, 13.3$ to 29.0$)$

$2829 / 6275$ (34.9\%, 23.3 to 48.6 )

$1166 / 5113(17.1 \%, 10.1$ to 27.5$)$

$521 / 2228(18.0 \%, 9.0$ to 32.8$)$

$20 / 455$ (4.5\%, 2.9 to 6.9$)$

$423 / 2113(20.0 \%, 18.4$ to 21.8$)$

$6 / 49(12.3 \%, 5.6$ to 24.7$)$

$98 / 201(48.8 \%, 41.9$ to 55.6$)$

1391/5576 (15.6\%, 7.1 to 30.7$)$

$943 / 5352(11.7 \%, 4.6$ to 26.7$)$

$21 / 344(10.1 \%, 0.8$ to 60.8$)$

$3 / 318(1.7 \%, 0.1$ to 23.7$)$

$4 / 386(1.9 \%, 0.2$ to 18.5$)$

$7 / 26(26.9 \%, 13.4$ to 46.7$)$

$641 / 6363(9.5 \%, 4.6$ to 18.4$)$

$266 / 2463(6.7 \%, 3.4$ to 12.9$)$

$23 / 731(2.7 \%, 1.0$ to 7.0$)$

$5 / 49(10.2 \%, 4.3$ to 22.3$)$

$1 / 27(3.7 \%, 0.5$ to 22.1$)$

$1 / 27$ (3.7\%, 0.5 to 22.1$)$

$1 / 27(3.7 \%, 0.5$ to 22.1$)$

$4872 / 8520$ (46.1\%, 32.9 to 59.8$)$

$1297 / 6279$ (16.4\%, 7.75 to 31.4$)$

$384 / 1179$ (30.4\%, 16.8 to 48.6$)$

$4 / 382(2.0 \%, 0.1$ to $45.5 \%)$

$1 / 27$ (3.7\%, 0.5 to 22.1$)$

$689 / 2113(30.0 \%, 31.1$ to 35.7$)$
$<0.01(2.8,99.2 \%)$
$<0.01(2.7,99.0 \%)$
$<0.01(3.9,97.7 \%)$
$<0.01(0.4,95.4 \%)$
$0.28(0.0,13.6 \%)$
NA
NA
NA
NA
NA
NA
NA
NA
NA

$<0.01(1.9,98.8 \%)$

$<0.01(1.5,98.0 \%)$

$<0.01(0.5,87.6 \%)$

$0.6(0,0.0 \%)$

NA

NA

NA

$<0.01(2.5,98.9 \%)$

$<0.01(1.8,99.1 \%)$

$<0.01(2.3,94.9 \%)$

$0.02(3.7,82.7 \%)$

$0.01(2.6,83.4 \%)$

NA

$<0.01(1.3,98.5 \%)$

$<0.01(0.4,72.5 \%)$

$<0.01(0.5,71.3 \%)$

NA

NA

NA

NA

$<0.01(1.9,99.0 \%)$

$<0.01(2.3,99.2 \%)$

$<0.01(0.8,95.9 \%)$

$<0.01(6.5,90.4 \%)$

NA

NA 
medRxiv preprint doi: https://doi.org/10.1101/2021.07.17.21260655; this version posted July 20, 2021. The copyright holder for this preprint (which was not certified by peer review) is the author/funder, who has granted medRxiv a license to display the preprint in perpetuity. All rights reserved. No reuse allowed without permission.

$\begin{array}{llll}\begin{array}{l}\text { Sarcopenia } \\ \text { tological }\end{array} & 1 & 11 / 11(95.8 \%, 57.5 \text { to } 99.7) & \text { NA } \\ \text { Alopecia } & 7 & 685 / 3622(17.5 \%, 9.1 \text { to } 30.9) & <0.01(0.93,98.2 \%) \\ \text { Rash } & 4 & 129 / 2690(2.3 \%, 0.6 \text { to } 8.3) & \text { NA } \\ \text { Allodynia } & 1 & 1 / 27(3.7 \%, 0.5 \text { to } 22.1) & \text { NA } \\ \text { Eczema } & 1 & 1 / 31(3.2 \%, 0.5 \text { to } 19.6) & \text { NA } \\ \text { Hyperhidrosis } & 1 & 3 / 27(11.1 \%, 3.6 \text { to } 29.3) & \text { NA } \\ \text { Hypohidrosis } & 1 & 1 / 27(3.7 \%, 0.5 \text { to } 22.1) & \mathrm{NA} \\ \text { Red spots on toes } & 1 & 42 / 2113(2.0 \%, 1.5 \text { to } 2.7) & \mathrm{NA} \\ \text { atric } & & & <0.01(1.6,99.0 \%) \\ \text { Insomnia/Sleep disorders } & 13 & 1367 / 5666(19 \%, 10.6 \text { to } 32.6) & <0.01(0.8,97.3 \%) \\ \text { Anxiety/Depression } & 12 & 835 / 3861(24.5 \%, 16.2 \text { to } 35.1) & <0.01(2.2,97.5 \%) \\ \text { Impaired concentration } & 5 & 252 / 1029(22.8 \%, 7.1 \text { to } 53.4) & <0.01(1.6,90.6 \%) \\ \text { Attention deficit } & 3 & 26 / 183(22.2 \%, 5.99 \text { to } 56.0) & <0.01(0.2,82.0 \%) \\ \text { Post-traumatic stress } & 3 & 133 / 307(42.5 \%, 30.0 \text { to } 56.1) & \mathrm{NA} \\ \text { Adjustment disorder } & 1 & 5 / 355(1.4 \%, 0.6 \text { to } 0.3) & \mathrm{NA} \\ \begin{array}{l}\text { Obsessive compulsive } \\ \text { disorder }\end{array} & 1 & 14 / 287(4.9 \%, 2.9 \text { to } 8.1) & \mathrm{NA} \\ \text { Panic attack } & & 98 / 734(13.4 \%, 11.1 \text { to } 16.0) & \mathrm{NA}\end{array}$

$\mathrm{TaU}^{2}$ is the variance of the effect size parameters across the population of studies, and it reflects the variance of the true effect size (i.e., heterogeneity among studies). $I^{2}$ refers to the percentage of heterogenetic among the included studies. NA: Not applicable/available; Estimation was done assuming a random effects model.

${ }^{a}$ Results were ordered according to the number of articles included in each meta-analysis.

${ }^{\mathrm{b}}$ COVID-19 represents the total of patients reported in selected articles. 
medRxiv preprint doi: https://doi.org/10.1101/2021.07.17.21260655; this version posted July $20,2021$. The copyright holder for this preprint (which was not certified by peer review) is the author/funder, who has granted medRxiv a license to display the preprint in perpetuity.

All rights reserved. No reuse allowed without permission.

Table 4. Cluster analysis based on autonomic symptoms in post-COVID patients.

\begin{tabular}{|c|c|c|c|}
\hline Variable & Cluster 1 (n: 69) & Cluster 2 (n: 31) & P value \\
\hline \multicolumn{3}{|l|}{ Sex } & 0.2873 \\
\hline Female & $34(49.3 \%)$ & $19(61.3 \%)$ & \\
\hline Male & $35(50.7 \%)$ & $12(38.7 \%)$ & \\
\hline Age (Median -IQR) & 50 (41 to 55$)$ & 48 (37 to 55.5$)$ & 0.3748 \\
\hline Body mass index (Median -IQR) & $28(25.2$ to 30.2$)$ & $28.1(25$ to 31.4$)$ & 0.9021 \\
\hline Post-COVID time (days, Median -IQR) & Comorbidities (Prior COVID-19) & 228 (207 to 257.5 ) & 0.1177 \\
\hline Hypertension & $12(17.4 \%)$ & $5(16.1 \%)$ & 1.0000 \\
\hline Diabetes type 2 & $10(14.5 \%)$ & $5(16.1 \%)$ & 1.0000 \\
\hline COPD & $1(1.4 \%)$ & $0(0.0 \%)$ & 1.0000 \\
\hline Cancer & $0(0.0 \%)$ & $1(3.2 \%)$ & 0.3100 \\
\hline Dyslipidemia & $9(13.0 \%)$ & $3(9.7 \%)$ & 0.7495 \\
\hline Kidney disease & $2(2.9 \%)$ & $1(3.2 \%)$ & 1.0000 \\
\hline Hypothyroidism & $9(13.0 \%)$ & $3(9.7 \%)$ & 0.7495 \\
\hline Asthma & $0(0.0 \%)$ & $0(0.0 \%)$ & - \\
\hline Coronary artery disease & $0(0.0 \%)$ & $0(0.0 \%)$ & - \\
\hline \multicolumn{4}{|l|}{ Clinical management } \\
\hline Hospitalization & $43(62.3 \%)$ & $22(71.0 \%)$ & 0.4986 \\
\hline Days of hospitalization (Median -IQR) & 11 (8 to 17$)$ & $12(7.3$ to 15.8$)$ & 0.8339 \\
\hline ICU & $15(34.9 \%)$ & $9(40.9 \%)$ & 0.7866 \\
\hline Days of ICU (Median -IQR) & 9.5 (4.5 to 13$)$ & $12(7$ to 15$)$ & 0.4678 \\
\hline \multicolumn{4}{|l|}{ Acute COVID-19 symptoms } \\
\hline Anosmia & 32 (46.4\%) & $19(61.3 \%)$ & 0.1981 \\
\hline Ageusia & $34(49.3 \%)$ & $19(61.3 \%)$ & 0.2873 \\
\hline Fatigue & $50(72.5 \%)$ & $29(93.5 \%)$ & 0.0173 \\
\hline Headache & $41(59.4 \%)$ & $26(83.9 \%)$ & 0.0210 \\
\hline Dry cough & $43(62.3 \%)$ & $18(58.1 \%)$ & 0.8249 \\
\hline Rhinorrhea & $23(33.3 \%)$ & $11(35.5 \%)$ & 0.8239 \\
\hline Pharyngitis & $31(44.9 \%)$ & $17(54.8 \%)$ & 0.3931 \\
\hline Dizziness & $20(29.0 \%)$ & $15(48.4 \%)$ & 0.0722 \\
\hline Confusion & $12(17.4 \%)$ & $9(29.0 \%)$ & 0.1960 \\
\hline Impaired visual acuity & $4(5.8 \%)$ & $9(29.0 \%)$ & $0.0028^{*}$ \\
\hline Blurry vision & $6(8.7 \%)$ & $12(38.7 \%)$ & $0.0006^{*}$ \\
\hline Dyspnea & $35(50.7 \%)$ & 24 (77.4\%) & 0.0155 \\
\hline Diarrhea & $22(31.9 \%)$ & $18(58.1 \%)$ & 0.0163 \\
\hline Vomiting & $13(18.8 \%)$ & $6(19.4 \%)$ & 1.0000 \\
\hline Myalgia & $40(58.0 \%)$ & $26(83.9 \%)$ & 0.0126 \\
\hline Arthralgia & $40(58.0 \%)$ & $22(71.0 \%)$ & 0.2681 \\
\hline Edema & $5(7.2 \%)$ & $5(16.1 \%)$ & 0.2773 \\
\hline Fever & $40(58.0 \%)$ & $22(71.0 \%)$ & 0.2681 \\
\hline \multicolumn{4}{|l|}{ Post-COVID symptoms } \\
\hline Depression & $13(18.8 \%)$ & $19(61.3 \%)$ & $<0.0001^{*}$ \\
\hline New onset $A D$ & $0(0.0 \%)$ & $2(6.5 \%)$ & 0.0939 \\
\hline Anorexia & $10(14.5 \%)$ & $13(41.9 \%)$ & 0.0043 \\
\hline Chills & $5(7.2 \%)$ & $14(45.2 \%)$ & $<0.0001^{*}$ \\
\hline Weight Loss & $10(14.5 \%)$ & $10(32.3 \%)$ & 0.0576 \\
\hline Exanthema & $15(21.7 \%)$ & $11(35.5 \%)$ & 0.2170 \\
\hline Blisters & $3(4.3 \%)$ & $5(16.1 \%)$ & 0.1031 \\
\hline Skin sensitivity & $7(10.1 \%)$ & $8(25.8 \%)$ & 0.0666 \\
\hline Sarcopenia & $13(18.8 \%)$ & $15(48.4 \%)$ & 0.0037 \\
\hline Weakness & $22(31.9 \%)$ & $24(77.4 \%)$ & $<0.0001^{*}$ \\
\hline Diarrhea & $23(33.3 \%)$ & $23(74.2 \%)$ & $0.0002^{*}$ \\
\hline Myalgia & $19(27.5 \%)$ & $23(74.2 \%)$ & $<0.0001^{*}$ \\
\hline Back pain & $27(39.1 \%)$ & $28(90.3 \%)$ & $<0.0001^{*}$ \\
\hline
\end{tabular}




\begin{tabular}{|c|c|c|c|}
\hline Arms/legs heaviness & $21(30.4 \%)$ & $26(83.9 \%)$ & $<0.0001^{*}$ \\
\hline Inability to walk & $4(5.8 \%)$ & $12(38.7 \%)$ & $<0.0001^{*}$ \\
\hline Fatigue & $13(18.8 \%)$ & $21(67.7 \%)$ & $<0.0001^{*}$ \\
\hline Body pain & $14(20.3 \%)$ & $26(83.9 \%)$ & $<0.0001^{*}$ \\
\hline Arthralgia & $37(53.6 \%)$ & $28(90.3 \%)$ & $0.0003^{*}$ \\
\hline Palpitations & $11(15.9 \%)$ & $16(51.6 \%)$ & $0.0005^{\star}$ \\
\hline Xerostomia & $9(13.0 \%)$ & $17(54.8 \%)$ & $<0.0001^{*}$ \\
\hline Chest tightness & $12(17.4 \%)$ & $18(58.1 \%)$ & $<0.0001^{*}$ \\
\hline Tachycardia & $11(15.9 \%)$ & $18(58.1 \%)$ & $<0.0001^{*}$ \\
\hline Edema & $2(2.9 \%)$ & $10(32.3 \%)$ & $0.0001^{*}$ \\
\hline Chest pain & $14(20.3 \%)$ & 15 (48.4\%) & 0.0079 \\
\hline Hemoptysis & $1(1.4 \%)$ & $0(0.0 \%)$ & 1.0000 \\
\hline Dyspnea & $13(18.8 \%)$ & $11(35.5 \%)$ & 0.0818 \\
\hline Wet cough & $5(7.2 \%)$ & $5(16.1 \%)$ & 0.2773 \\
\hline Dry cough & $8(11.6 \%)$ & 9 (29.0\%) & 0.0442 \\
\hline Pleurisy & $7(10.1 \%)$ & $9(29.0 \%)$ & 0.0354 \\
\hline Rhinorrhea & $9(13.0 \%)$ & $10(32.3 \%)$ & 0.0301 \\
\hline Sickness & $10(14.5 \%)$ & $9(29.0 \%)$ & 0.1028 \\
\hline Abdominal pain & $10(14.5 \%)$ & $14(45.2 \%)$ & 0.0019 \\
\hline Paresthesia & $17(24.6 \%)$ & $21(67.7 \%)$ & $0.0001^{*}$ \\
\hline Attention disorders & $15(21.7 \%)$ & $21(67.7 \%)$ & $<0.0001^{*}$ \\
\hline Memory disorders & $12(17.4 \%)$ & $24(77.4 \%)$ & $<0.0001^{*}$ \\
\hline Seizures & $0(0.0 \%)$ & $1(3.2 \%)$ & 0.3100 \\
\hline Headache & $20(29.0 \%)$ & 25 (80.6\%) & $<0.0001^{*}$ \\
\hline Dizziness & $11(15.9 \%)$ & 20 (64.5\%) & $<0.0001^{*}$ \\
\hline Xerophthalmia & $10(14.5 \%)$ & $13(41.9 \%)$ & 0.0043 \\
\hline Tooth Loss & $0(0.0 \%)$ & $2(6.5 \%)$ & 0.0939 \\
\hline Tinnitus & $9(13.0 \%)$ & $14(45.2 \%)$ & $0.0008^{*}$ \\
\hline Anosmia & $6(8.7 \%)$ & $5(16.1 \%)$ & 0.3089 \\
\hline Ageusia & $8(11.6 \%)$ & $7(22.6 \%)$ & 0.2243 \\
\hline Vision disorders & $8(11.6 \%)$ & $13(41.9 \%)$ & $0.0011^{*}$ \\
\hline Eye pain & $11(15.9 \%)$ & $16(51.6 \%)$ & $0.0005^{\star}$ \\
\hline Pharyngitis & $7(10.1 \%)$ & $12(38.7 \%)$ & 0.0017 \\
\hline Alopecia & $7(10.1 \%)$ & $6(19.4 \%)$ & 0.2152 \\
\hline Erectile dysfunction & $2(2.9 \%)$ & $1(3.2 \%)$ & 1.0000 \\
\hline Insomnia & $0(0.0 \%)$ & $1(3.2 \%)$ & 0.3100 \\
\hline COMPASS 31 score (Median -IQR) & $6(3-9)$ & $22(18-26)$ & $<0.0001$ \\
\hline Zung score (Median -IQR) & $32(26-37)$ & $40(36.5-47)$ & $<0.0001$ \\
\hline Thyroid stimulating hormone ( $\mu$ IU /mL) (Median -IQR) & 2.14 (1.4 to 3.2$)$ & $2.4(2.0$ to 3.5$)$ & 0.2465 \\
\hline $\begin{array}{l}\text { Total anti-SARS-CoV-2 antibodies (U/mL) (Median - } \\
\text { IQR) }\end{array}$ & $701.6(220.7-1481)$ & $1258(336.5-1945)$ & 0.2395 \\
\hline \multicolumn{4}{|c|}{$\begin{array}{l}\text { IQR: Interquartile range; ICU: Intensive care unit; COPD: Chronic pulmonary obstructive disease; } \\
\text { AD: Autoimmune disease; COMPASS 31: Composite Autonomic Symptom Score 31; COVID-19: } \\
\text { Coronavirus disease 2019; SARS-CoV-2: Severe acute respiratory syndrome coronavirus 2; } \\
\text { Thyroid stimulating hormone, by electroquimioluminiscence using the following thresholds: } \\
0.3-4.5 \mu \mathrm{IU} / \mathrm{mL} \text {. } \\
{ }^{a} \mathrm{P} \text { values for categorical variables were obtained by Fisher's exact test. Quantitative variables were } \\
\text { analyzed by Mann-Whitney U test. } \\
\text { * Statistically significant after Bonferroni correction. P value threshold for acute COVID-19 } \\
\text { symptoms: } 0.05 / 18=0.0028 ; P \text { value threshold for post-COVID symptoms: } 0.05 / 47=0.0011 \text {. }\end{array}$} \\
\hline
\end{tabular}

Arms/legs heaviness

Fatigue

Body pain

Xerostomia

Chest tightness

Dyspnea

Wet cough

Rhinorrhea

Sickness

Abdominal pain

Attention disorders

Memory disorders

Xerophthalmia

Tooth Loss

Ageusia

Vision disorders

Erectile dysfunction

Insomnia

COMPASS 31 score (Median -IQR)

Total anti-SARS-CoV-2 antibodies (U/mL) (Median -

IQR: Interquartile range; ICU: Intensive care unit; COPD: Chronic pulmonary obstructive disease;

Thyroid stimulating hormone, by electroquimioluminiscence using the following thresholds:

$0.3-4.5 \mu \mathrm{IU} / \mathrm{mL}$.

P values for categorical variables were obtained by Fisher's exact test. Quantitative variables were

Statistically significant after Bonferroni correction. $P$ value threshold for acute COVID-19 作: 0.0028 ; $P$ value threshold for post-COVID symptoms: $0.05 / 47=0.0011$ 
Figure 1. Preferred Reporting Items for Systematic Reviews and Metaanalyses (PRISMA) flow chart.

Figure 2. Acute and post-COVID symptoms. A. Frequency bar plot for clinical manifestations on acute COVID-19. B. Frequency bar plot for post-COVID clinical manifestations. Frequency of depression was estimated by Zung scale. C. Venn diagram with the superposition of the main PCS symptoms. Analysis included 91 patients, because 9 out of 100 patients did not exhibit any of the four main symptoms. D. Mirrored bar plot for symptoms on acute COVID-19 and post-COVID syndrome.

Figure 3. Anti RBD SARS-CoV-2 antibodies (see supplementary material 1 for details). A. Correlation between IgG anti-SARS-CoV-2 by ELISA (Euroimmun) and total anti-SARS-CoV-2 antibodies by ECLIA (Roche). B. Correlation between neutralizing anti-SARS-CoV-2 antibodies (PRNT ${ }_{50}$ ) and total anti-SARS-CoV-2 antibodies by ECLIA (Roche). C. Linear model for neutralizing antibodies based on ECLIA. D. ROC curve for the estimated cut-off value. The AUC represents the discrimination capacity of this threshold. E. Scatter plot for total anti-SARS-CoV-2 antibodies (by ECLIA, Roche) and post-COVID time. Line represents the locally estimated scatterplot smoothing with $95 \%$ confidence intervals.

Figure 4. Frequency bar plot for pooled prevalence of post-COVID manifestations in meta-analysis. Error bar represents the estimated $95 \%$ 
confidence interval. Only those clinical manifestations reported in more than 4 articles were included in this graph.

Figure 5. Autonomic clusters in post-COVID syndrome. A. Principal components of $K$-means clustering for weighted COMPASS 31 domains. COMPASS 31: composite autonomic symptom score 31. B. Mirrored bar plot for acute COVID-19 symptoms on cluster 1 and 2. C. Mirrored bar plot for post-COVID clinical manifestations on cluster 1 and 2 . 
medRxiv preprint doi: https://doi.org/10.1101/2021.07.17.21260655; this version posted July 20, 2021. The copyright holder for this preprint (which was not certified by peer review) is the author/funder, who has granted medRxiv a license to display the preprint in perpetuity.

All rights reserved. No reuse allowed without permission.

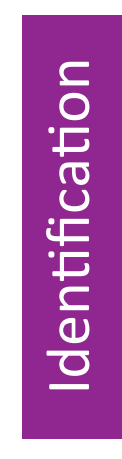

Articles identified in (PubMed)

First search with MeSH Terms:

Post-Covid, long Covid

$(n=1222)$

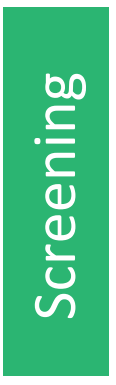

Duplicates

$(n=14)$

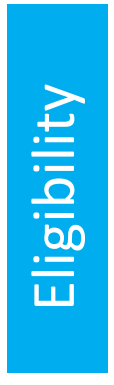

Potentially found articles

$(n=1222)$
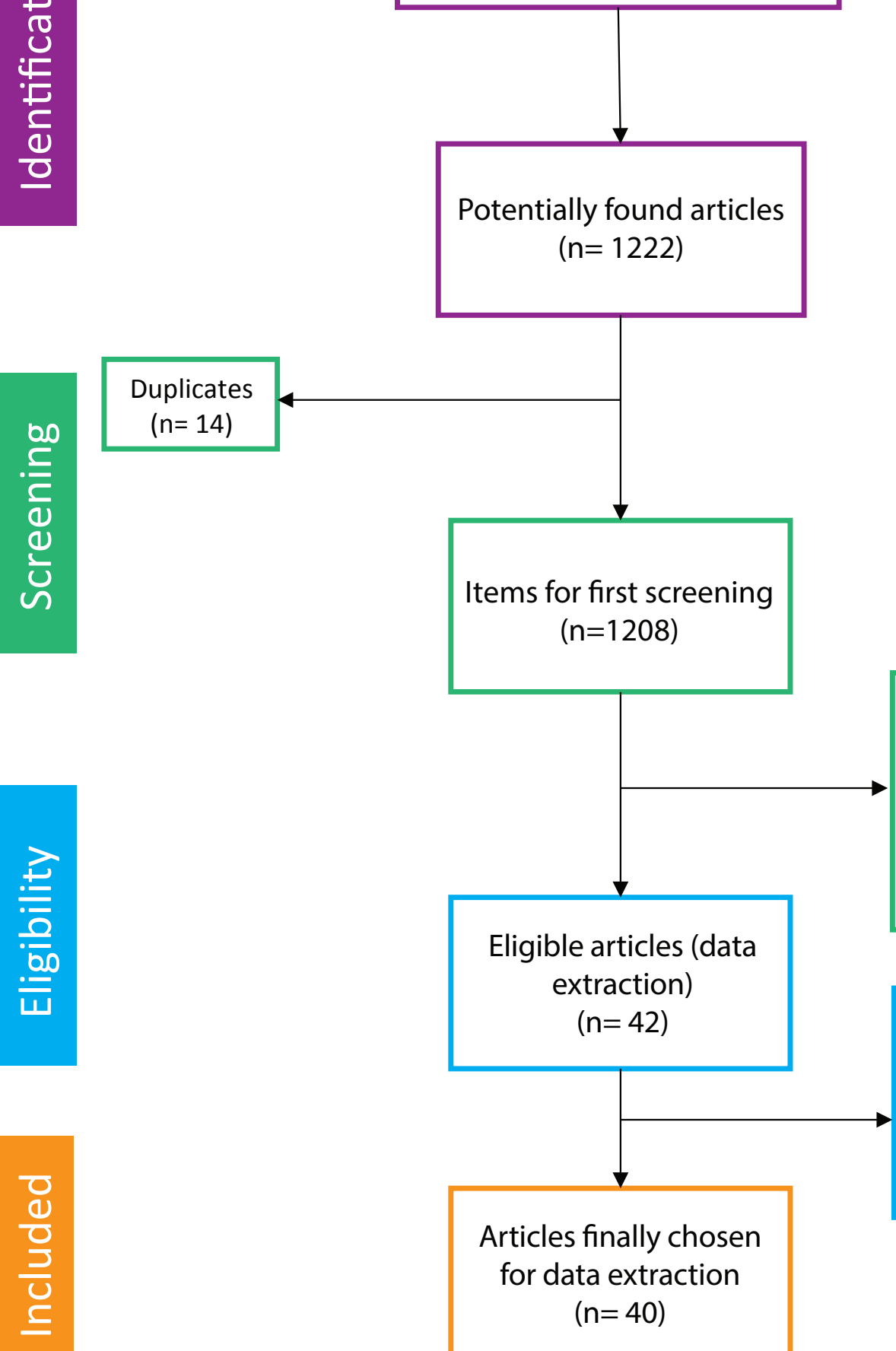

Excluded for being reviews, case reports, editorials, letters to the editor, non-medical articles, systematic reviews, unrelated topics $(n=1166)$

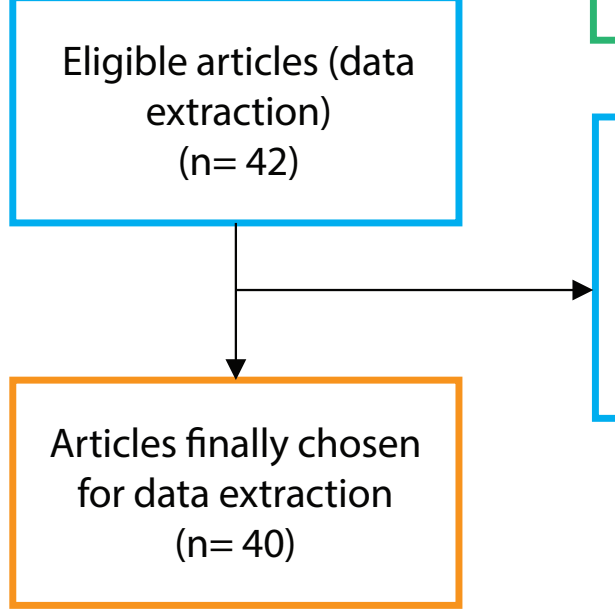

Studies that mention post-COVID clinical manifestations, but no patient data. $(n=2)$ 
Fatigue

HeadachedRxiv preprint doi: https://doi.org/10.1101/2021.07.17.21260655; this vepsiten ₹psosted July 20, 2021. The copyright holder for this preprint Myalgia (which was not certified by peer review) is the author/funder, who has graiafteeq anedBxiv a license to display the preprint in perpetuity.
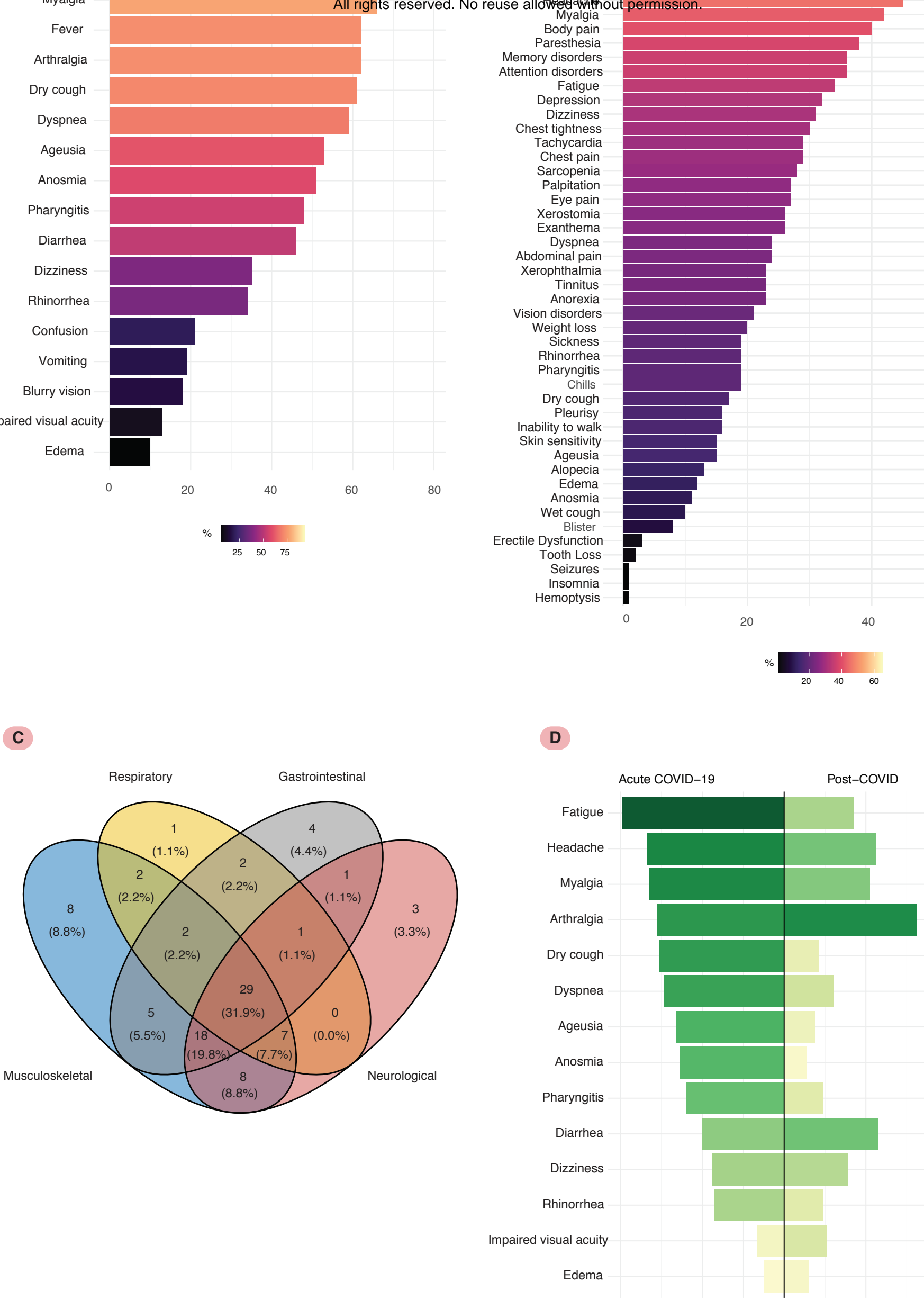


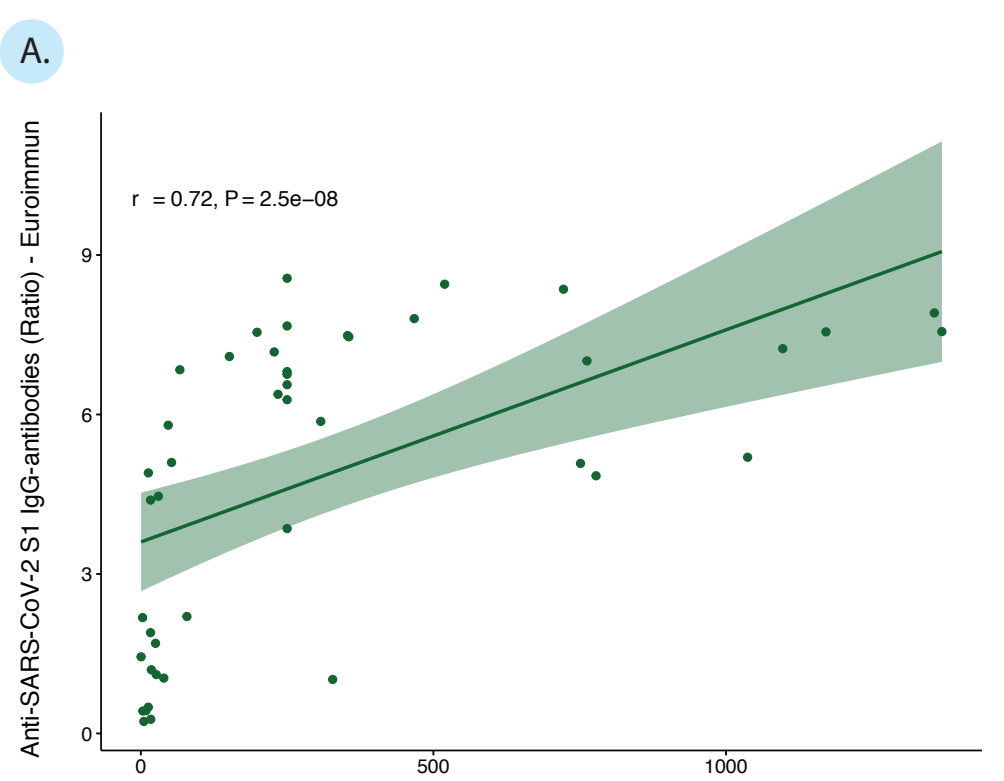

Total anti-SARS-CoV-2 RBD antibodies (U/mL) - Roche

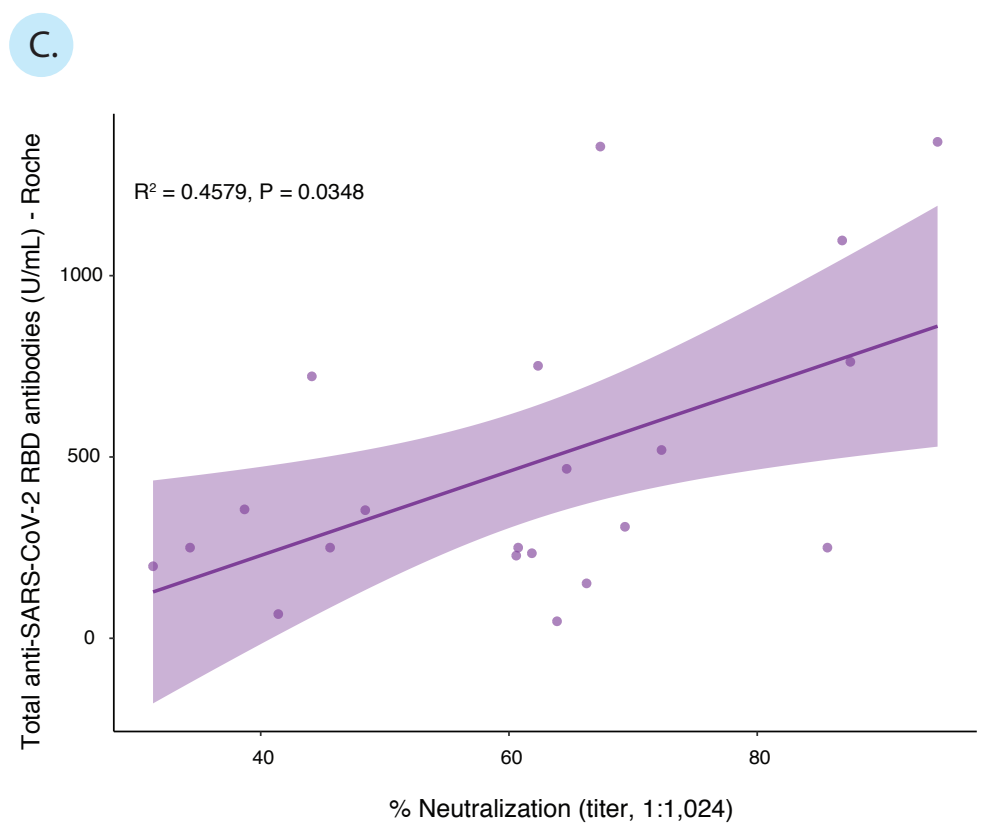

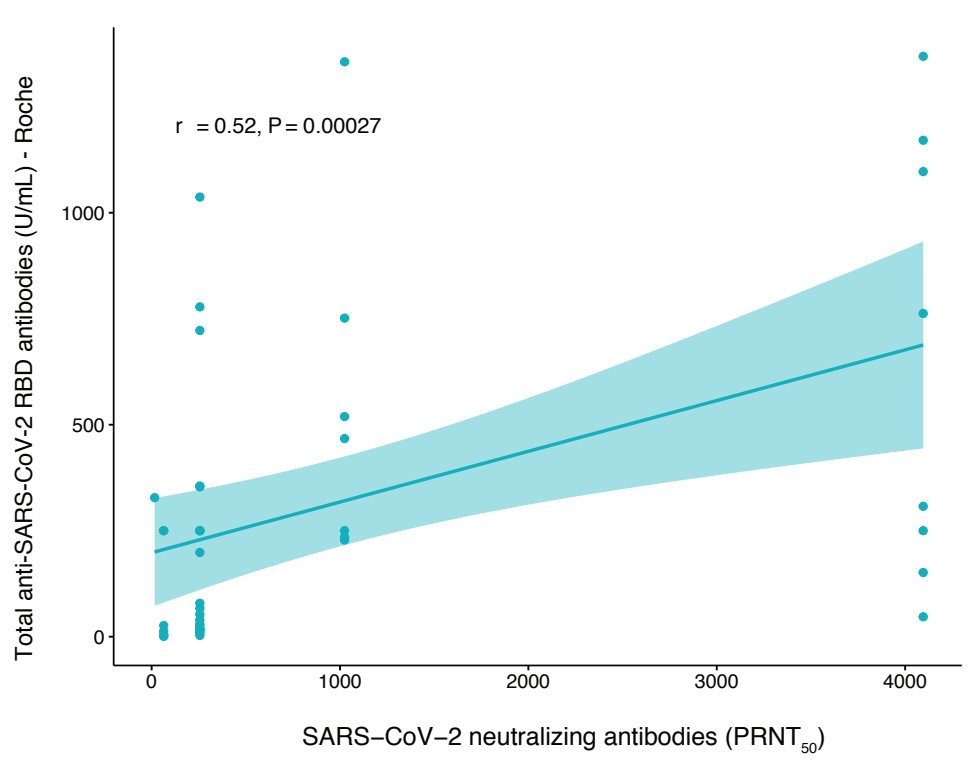

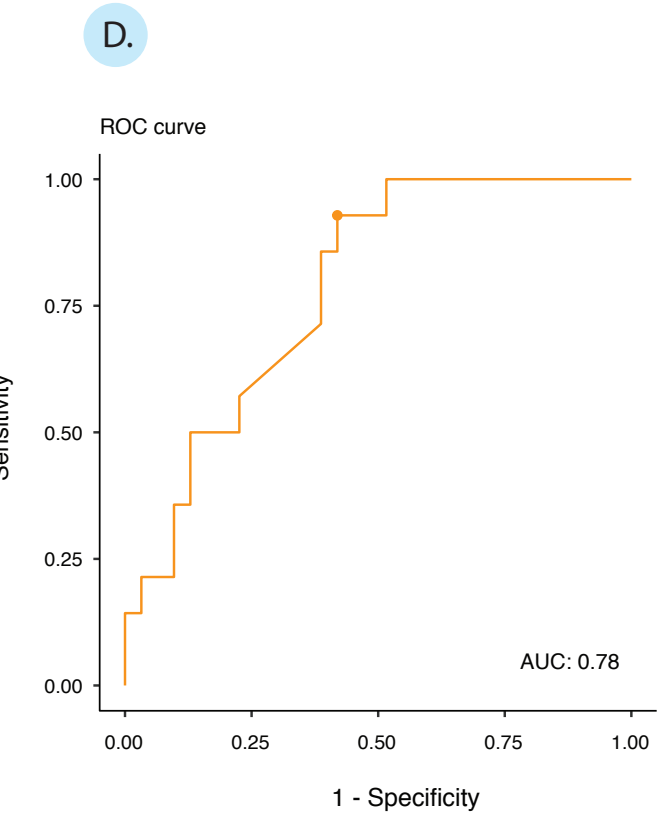

E.

\begin{tabular}{ll|}
\hline - Ambulatory \\
- Hospitalized \\
- ICU \\
\hline
\end{tabular}

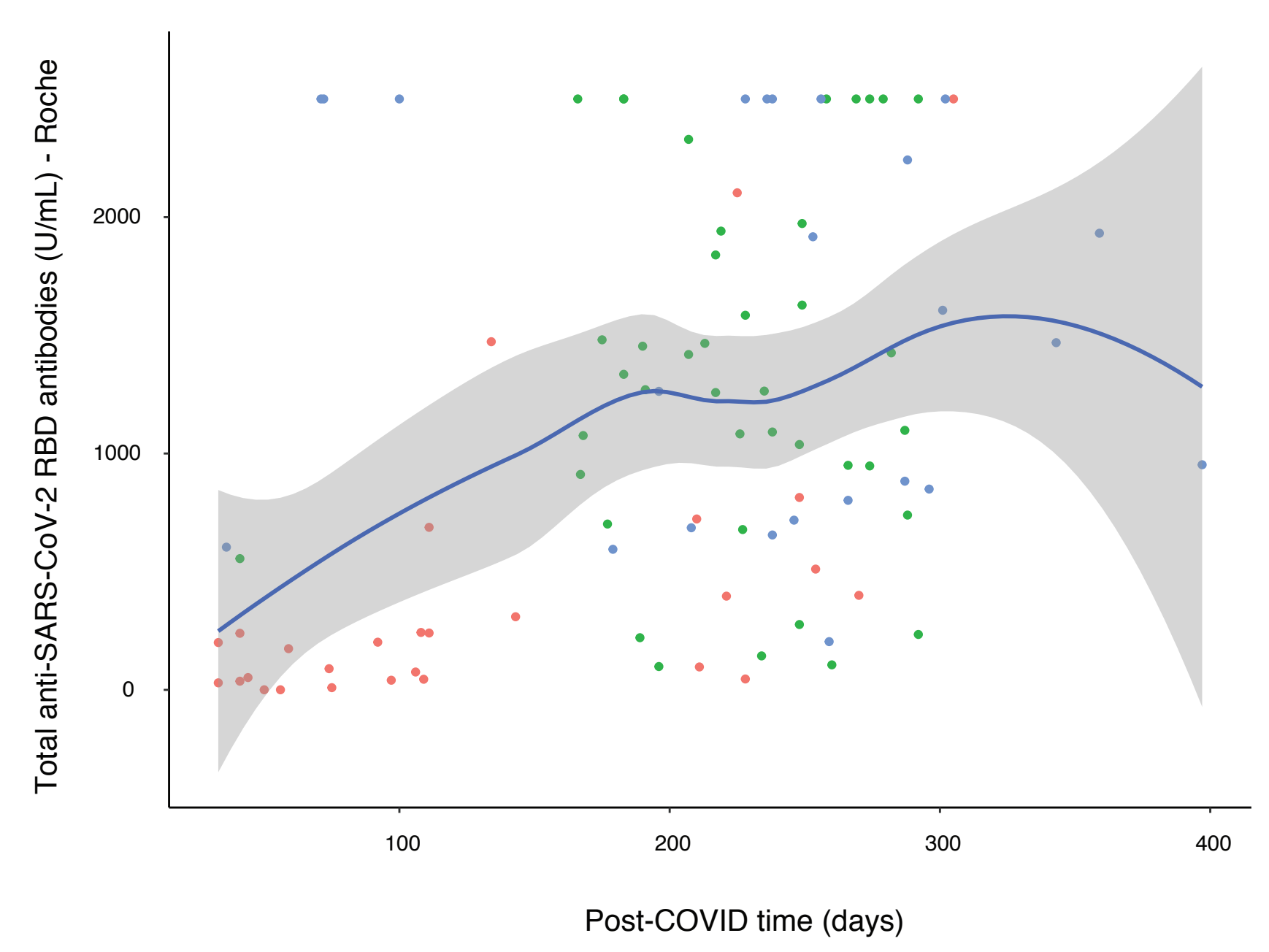


medRxiv preprint doi: https://doi.org/10.1101/2021.07.17.21260655; this version posted July 20, 2021. The copyright holder for this preprint (which was not certified by peer review) is the author/funder, who has granted medRxiv a license to display the preprint in perpetuity.

All rights reserved. No reuse allowed without permission.

Fatigue/Muscle weakness -

Dyspnea -

Pain and discomfort -

Anxiety/Depression -

Impaired concentration -

Insomnia/Sleep disorders -

Alopecia -

Cough -

Arthralgia/Myalgia -

Chest pain -

Cognitive impairment -

Dizziness -

Headache -

Sore throat -

Palpitations -

Anosmia -

Diarrhea/Vomiting -

Fever -

Blurry vision -

Ageusia -

Nasal congestion -

Anorexia -

Nausea -

Tinnitus -

Rash -

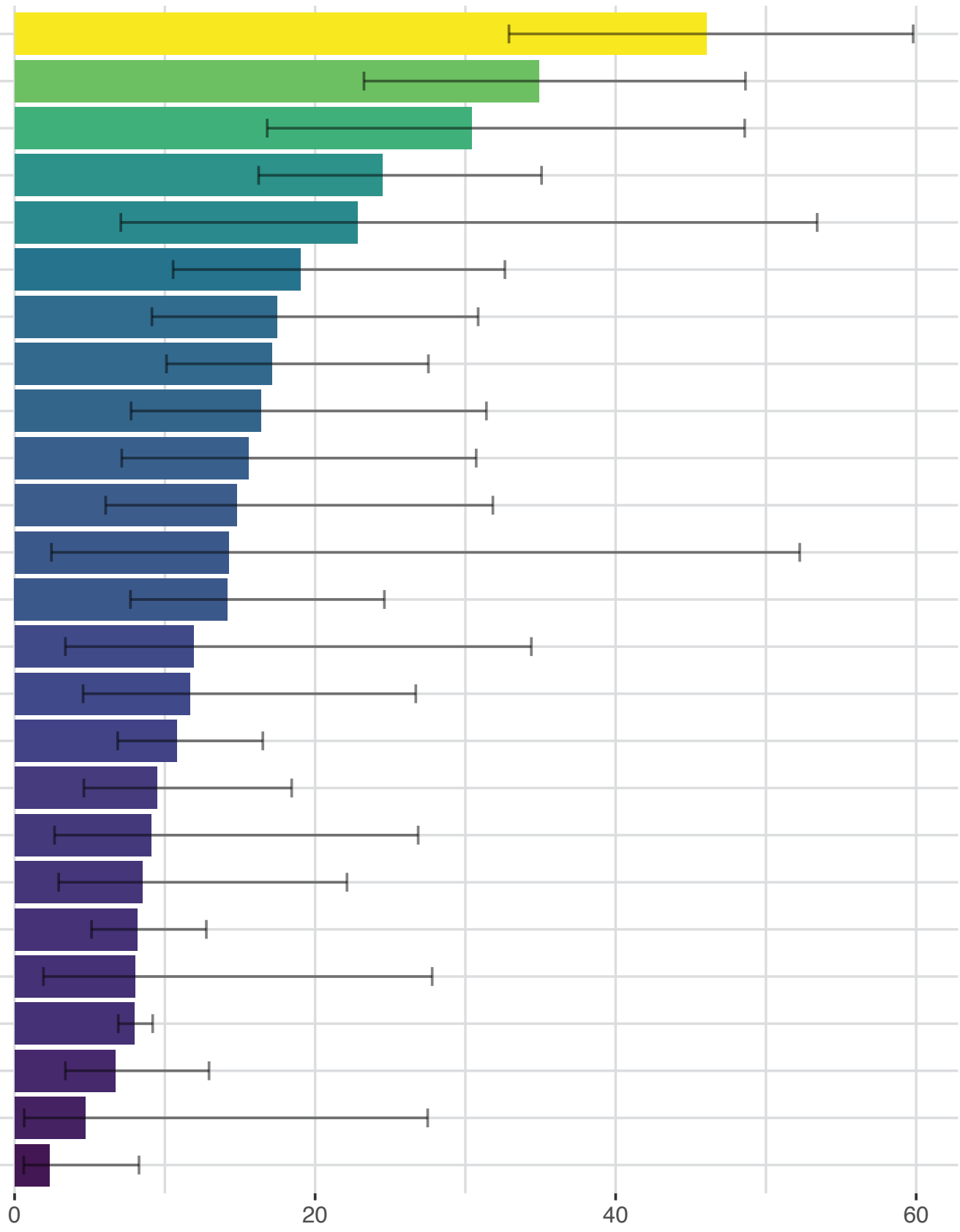


medRxiv preprint doi: https://doi.org/10.1101/2021.07.17.21260655; this version posted July 20, 2021. The copyright holder for this preprint (which was not certified by peer review) is the author/funder, who has granted medRxiv a license to display the preprint in perpetuity.

A All rights reserved. No reuse allowed without permission.

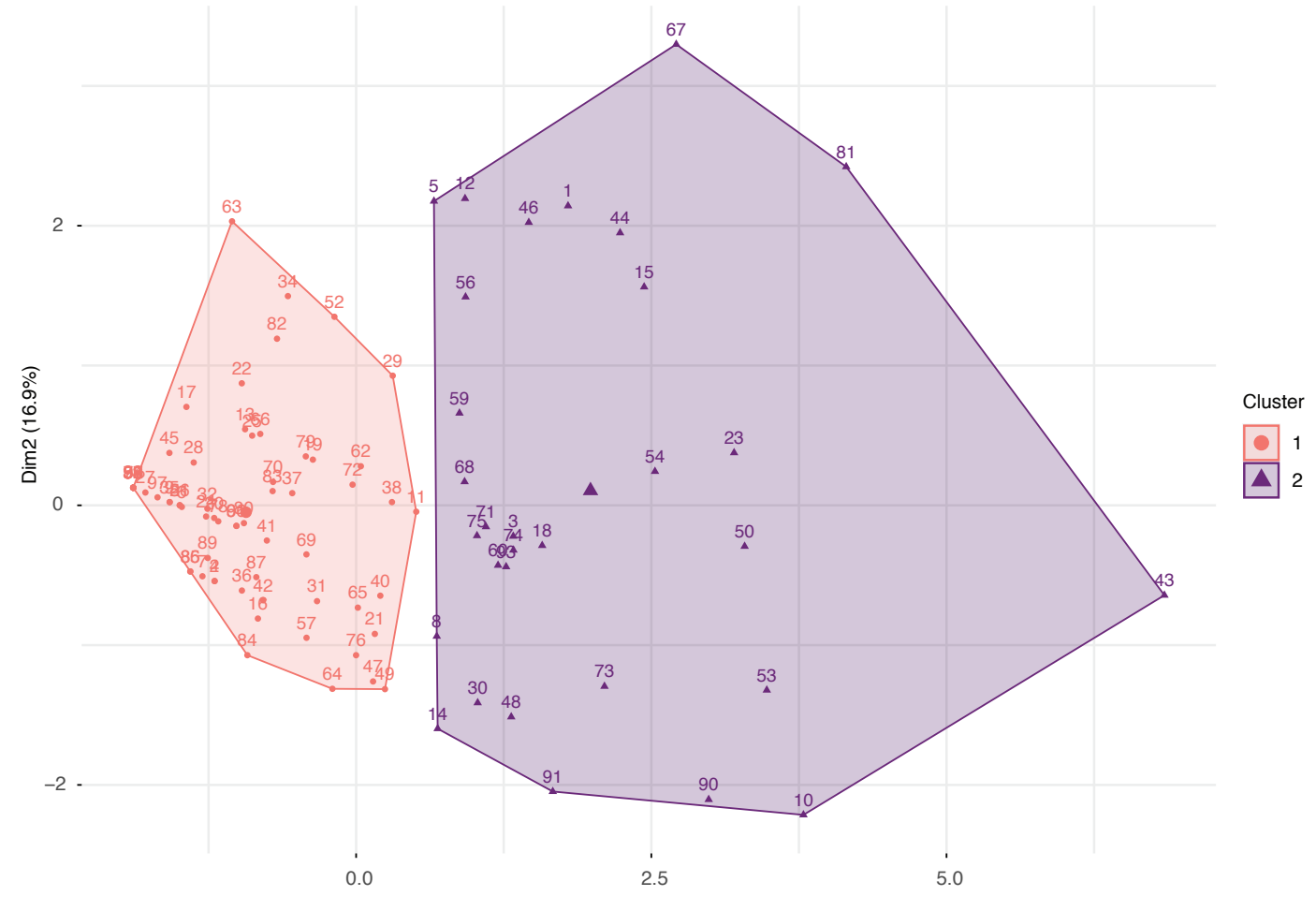

Dim1 (45.9\%)

B

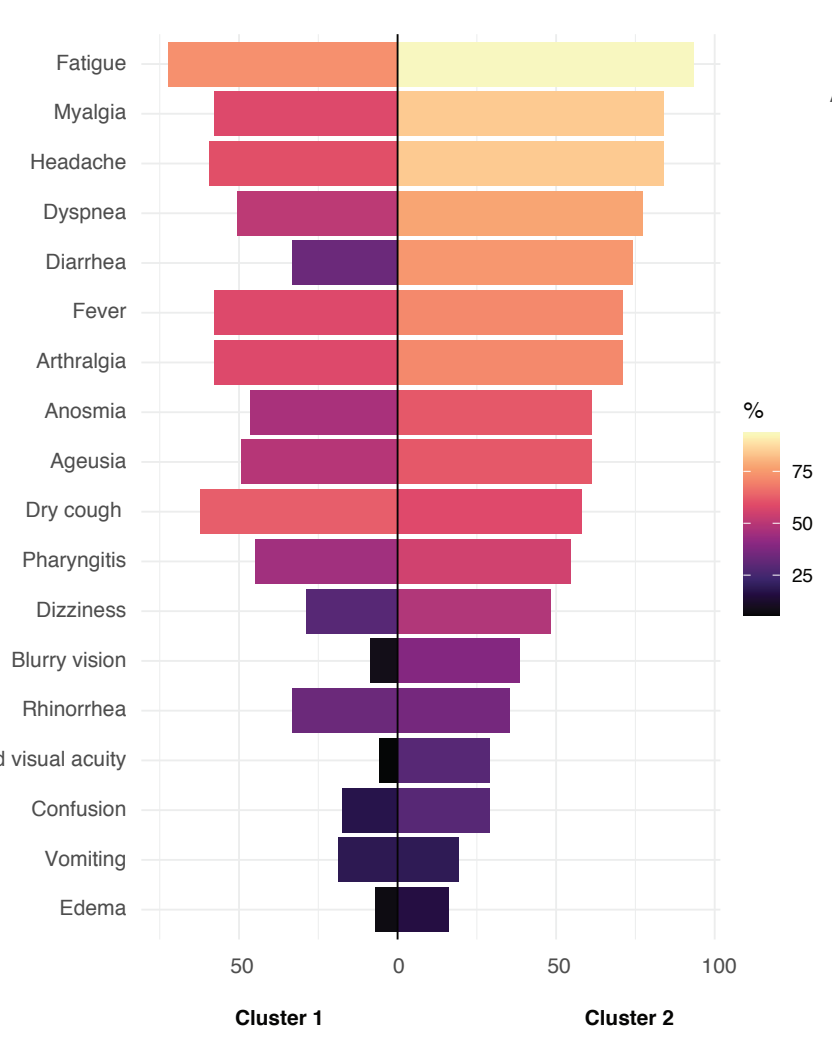

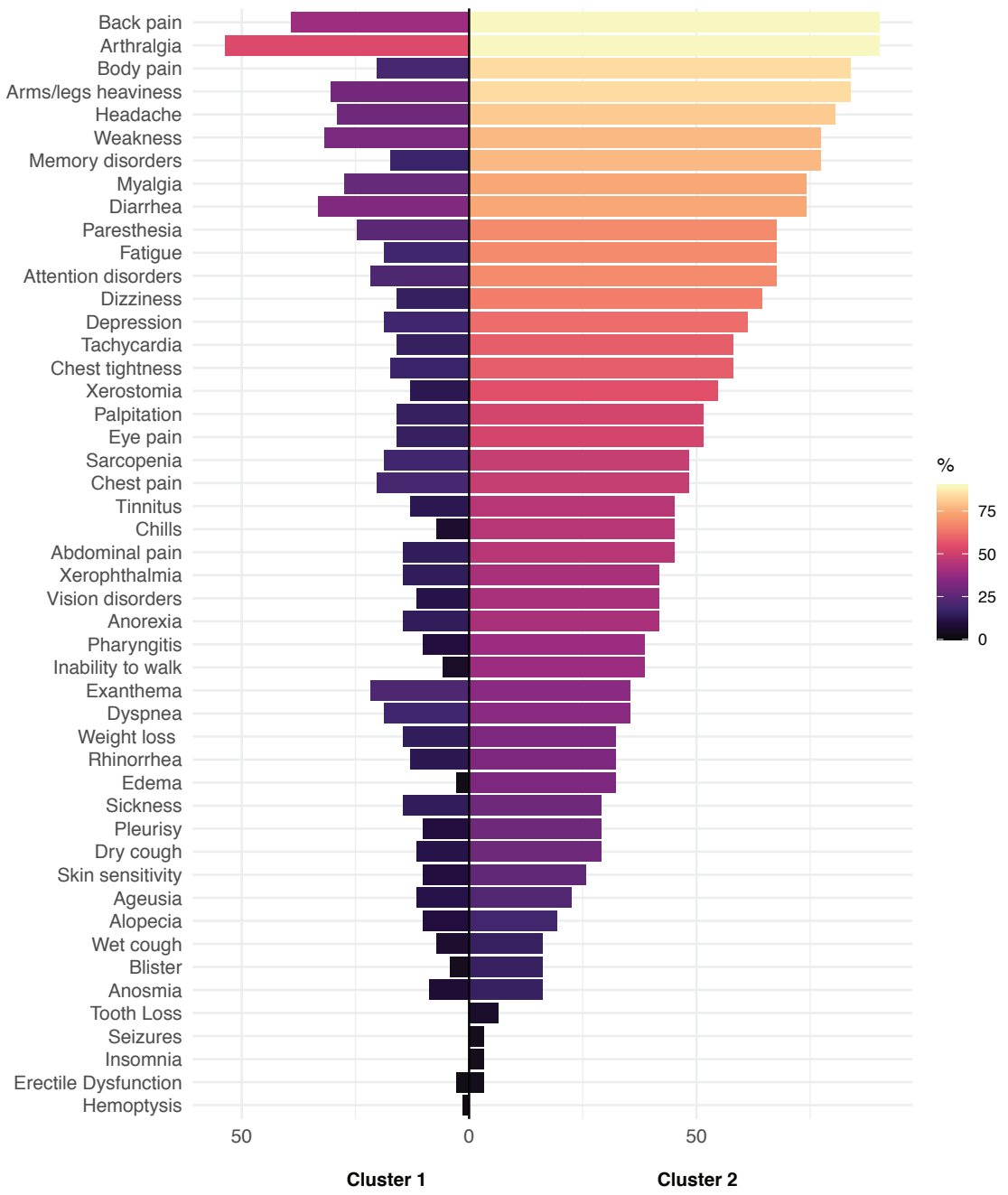

